\title{
Doris adrianae sp. nov. (Heterobranchia; Nudibranchia; Doridina) from the Galician coasts (NW Iberian Peninsula)
}

\author{
Doris adrianae sp. nov. (Heterobranchia; Nudibranchia; Doridina) \\ de las costas de Galicia (NW Península Iberica)
}

\author{
*Urgorri, V. ${ }^{1}$, Señarís, M.P. ${ }^{1}$, Díaz-Agras, G. ${ }^{1}$, Candás, M. ${ }^{1}$, \& Gómez-Rodríguez, C. ${ }^{2}$ \\ ${ }^{1}$ Estación de Bioloxía Mariña da Graña (REBUSC), Universidade de Santiago de Compostela, \\ rúa da Ribeira 1-4 (A Graña), 15590 Ferrol (Galicia), Spain. \\ ${ }^{2}$ Departamento de Bioloxía Funcional, Instituto CRETUS, Universidade de Santiago de \\ Compostela, rúa Lope Gómez de Marzoa, s/n. Campus Vida. \\ 15782 Santiago de Compostela (Galicia), Spain. \\ *Corresponding author: vituco.urgorri@usc.es
}

(Recibido: 15/02/2021; Aceptado: 02/03/2021)

\begin{abstract}
A new species of dorid nudibranch, Doris adrianae sp. nov. is described, from the Ría de Ferrol (NW Iberian Peninsula) on rocky bottoms, between 11 and $20 \mathrm{~m}$ deep, where its prey, the sponge Polymastia boletiformis (Lamarck, 1815) is common. The new species is oval-shaped and yellow to yellow-orange in colour, with the dorsum covered by rounded tubercles of various sizes, reinforced by tegumentary spicules. This new species is characterised by having numerous integumentary and fusiform calcareous spicules, mainly grouped in multispicular bundles resulting in a complex and very dense skeletal structure, giving the animal great consistence without losing flexibility. In addition, it differs from other known species of the genus Doris Linnaeus, 1758 by various external and internal characters, mainly by the coloration and the shape of the tubercles and the morphology of the radula, the digestive and reproductive systems. Doris adrianae sp. nov. also presents a marked genetic distance in the barcode fragment (cox1-5') with other species of the genus Doris.
\end{abstract}

Keywords: Gastropoda, Ría de Ferrol, anatomy, habitat, feeding, micro computed tomography.

\section{Resumen}

Se describe una nueva especie de un nudibranquio doridáceo, Doris adrianae sp. nov., recolectada en la Ría de Ferrol (NW Península Ibérica) en fondos de roca, entre 11 y $20 \mathrm{~m}$ de profundidad, donde es frecuente el porífero Polymastia boletiformis (Lamarck, 1815) del que se alimenta. La nueva especie tiene forma ovalada y de color amarillo a amarillo-anaranjado, con el dorso cubierto por tubérculos redondeados de varios tamaños, reforzados por espículas tegumentarias. Se caracteriza por presentar numerosas espículas calcáreas tegumentarias fusiformes, principalmente agrupadas en haces multiespiculares que le confieren una estructura esquelética compleja y muy densa, dándole al animal una gran consistencia sin perder flexibilidad. Además, se diferencia de otras especies conocidas del género Doris Linnaeus, 1758 por diversos caracteres externos e internos, principalmente por la coloración y tubérculos del cuerpo, caracteres de la rádula y de los aparatos 
digestivo y reproductor. Doris adrianae sp. nov. también presenta una marcada distancia genética en el fragmento "barcode" (coxl-5') con otras especies del género Doris.

Palabras clave: Gastropoda, Ría de Ferrol, anatomía, hábitat, alimentación, microtomografía computarizada.

\section{This paper is registered in Zoobank under:}

http://zoobank.org/urn:1sid:zoobank.org:pub:51C800B8-6F45-4F56-8E68-ED6D53ECF248

\section{Abbreviations}

a: anus

am: ampulla

ao: aorta

ar: adhesive region

au: auricle

ba: anterior blood gland

bb: buccal bulb

bc: bursa copulatrix

bg: buccal ganglion

bp: posterior blood gland

c: cerebral nerves

ca: caecum

cg: cerebral ganglion

cgl: capsule gland

$\mathrm{d}$ : deferent duct

dg: digestive gland

e: oesophagus

ey: eye

fg: female glands

g: branchial leaves

ga: genital atrium

go: genital openings

gpo: postampullar gonoduct

gpr: preampullar gonoduct

hdg: hermaphrodite and digestive glands

hg: hermaphrodite gland

i: intestine

m: mouth

mbb: buccal bulb muscle megl: membrane gland

mugl: mucous gland

mot: retractor muscles

og: gastro-oesophageal ganglion

ot: oral tube

ovp: proximal oviduct

ovd: distal oviduct

p: pedal nerves

pc: pedal commissure

pe: penis

pg: pedal ganglion

pl: pleural nerves

plg: pleural ganglion

ppc: parapedal commissure

pr: prostate

ps: penial sheath

pu: pericardium

r: rhinophoral nerves

rs: radular sac

sg: salivary gland

sr: seminal receptacle

st: stomach

sy: syrinx

ud: uterine duct

va: vagina

ve: ventricle

vgl: vestibular gland

vl: visceral loop

\section{INTRODUCTION}

The coasts of the Iberian Peninsula represent a zoogeographic enclave comprising two regions: Lusitanian and Mediterranean (Gofas, 2011). A total of 715 species of heterobranchs sea slugs are known from the Iberian Peninsula and the Balearic and
Canary Islands, of which 279 belong to the order Nudibranchia (Gofas, et al. 2017; Cervera, et al. 2004). Galicia (NW Iberian Peninsula) represent more than a third of the total coastline of the Iberian Peninsula, as it is heavily indented, with exposed environments 
open to the beating of the ocean and with deep coastal indentations called rías (RICHTHOFEN, 1886). The latter were formed by marine flooding of a terminal river course caused by the subsidence of the coastal edge and the rise in sea level. The rías vary greatly in size and orography, which determines the existence of a great diversity of habitats, from very rough to very sheltered environments, with a high diversity of flora and fauna (BAÑón, 2017).

The heterobranchs sea slugs of Galicia were poorly known until the last quarter of the 20th century, when URGORRI (1981) wrote his doctoral thesis and the first records and new species were published (ORTEA \& URGORRI, 1978, 1979a, 1979b, 1981a, 1981b; among others). URGORRI \& BESTEIRO (1983) published the inventory of the "opisthobranchs" of Galicia, in which they compiled the data from the doctoral thesis of URGORRI (1981) and all previous data, cataloguing 148 species from coastal and bathyal bottoms down to 3000 $\mathrm{m}$ depth. In subsequent years, the inventory was increased with new species and records, mainly of nudibranchs, by various authors (see UrgorRI, et al. 2011). Currently, 110 species of the order Nudibranchia are known from Galicia, of which 62 are classified in the suborder Cladobranchia and 48 in the suborder Doridina (Trigo, et al. 2018).

Three species of the genus Doris Linnaeus, 1758 are known in Galicia. These include Doris verrucosa Linnaeus, 1758 (URGORRI \& Besteiro, 1983, 1984; Rolán, 1983; Trigo \& Otero, 1987; Trigo, et al. 2018). Doris pseudoargus Rapp, 1827 (Urgorri \& Besteiro, 1983, 1984, both as Archidoris pseudoargus; Rolán (1983), as A. pseudoragus; Trigo, et al. 2018) and Doris ocelligera (Bergh, 1881 in Bergh 1881a) (Urgorri \& Besteiro, 1983, 1984; Rolán, 1983; Trigo, et al. 2018). All three species are well known from the Ría de Ferrol and found on rocky and gravel substrata in both the lower mesolittoral and infralittoral.

Twenty-two specimens of a dorid were collected at the Ría de Ferrol during the last 34 years, between 1986 and 2019, on a rocky bottom between 11 and $20 \mathrm{~m}$ deep, mostly under a gorgonian forest of Leptogorgia lusitanica (Stiasny, 1937). After its study, it was classified within the genus Doris according to VALDÉs (2002) and was found to be a new species described here as Doris adrianae sp. nov.

\section{MATERIAL AND METHODS}

Collection: The 22 specimens studied were collected by SCUBA diving, from rocky bottoms between 11 and $20 \mathrm{~m}$ deep in the localities of Punta Fornelos, Castelo de San Felipe and Punta Barbeira, at the Ría de Ferrol (NW Iberian Peninsula) (Fig. 1).

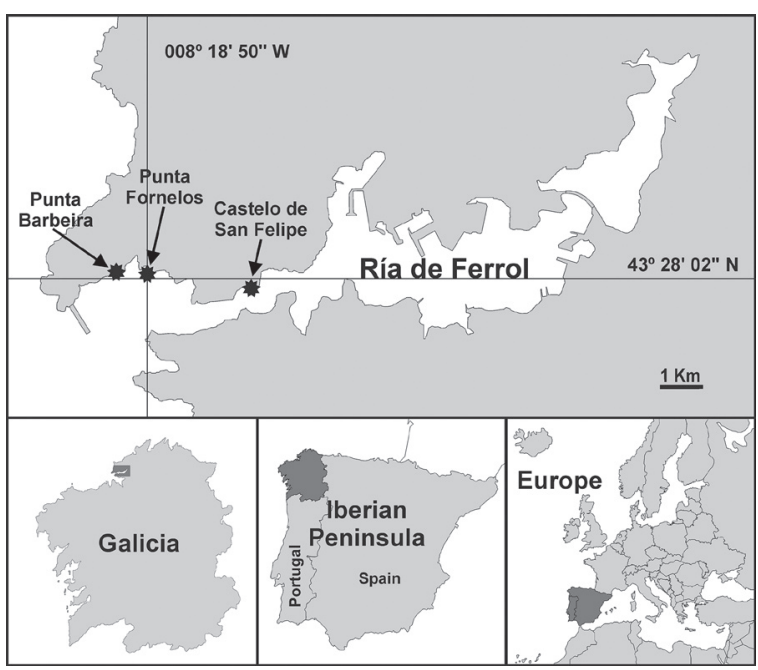

Figure 1. Map showing the type locality of Doris adrianae sp. nov. in Punta Fornelos, Castelo de San Felipe and Punta Barbeira at the Ría de Ferrol (NW Iberian Peninsula) where all specimens were collected.

Figura 1. Mapa que muestra la localidad tipo de Doris adrianae sp. nov. en Punta Fornelos, Castelo de San Felipe y Punta Barbeira en la Ría de Ferrol (NW Península Ibérica) donde se recolectaron todos los ejemplares.

They were collected mostly one specimen per sampling; only 6 times 2 specimens were collected together. In some samplings, in situ photographs of the animal, habitat and accompanying species were taken. Samples of porifera that could potentially be preyed upon by the dorid were also collected, in the same habitat. All specimens were observed in vivo and all characters that were lost after fixation were described. Some specimens were photographed in vivo in their habitat, although most were photographed in the laboratory. Both the general appearance of the animal and details of its external anatomy were captured, using 
an Olympus SCX12 stereo microscope with an Olympus E-330 digital camera. In addition, the animals were kept alive for 2 or 3 days in individualised aquaria for the collection of faeces and spawning.

Anaesthesia, fixation and preservation: All specimens were anaesthetised with 7\% magnesium chloride $(\mathrm{MgCl} 2)$, diluted in equal parts $(50 \%)$ in seawater and fresh water (URGORRI, 1981). After anaesthesing, the fixation process was carried out gradually, adding drops of the diluted fixative liquid with a Pasteur pipette, observing under the stereoscopic microscope if any reaction was produced in the animal, until complete fixation. The fixative liquid used was $70 \% \mathrm{EtOH}$ in 7 specimens, 100\% EtOH in 6 specimens and Bouin's fluid in 10 specimens; specimens fixed in $70 \% \mathrm{EtOH}$ and Bouin's fluid were preserved in $70 \% \mathrm{EtOH}$ neutralized with Borax to avoid degradation of the calcareous structures, while those fixed in $\mathrm{EtOH} 100^{\circ}$ were preserved in $\mathrm{EtOH} 100^{\circ}$ (for details see Type material and deposition).

Dissection, radula and labial disc preparations: For the study of the internal anatomy, paratypes $1,7,10,12$ and 17 were dissected under an Olympus SCX12 stereo microscope with an Olympus E-330 digital camera. After dissection, preparations of the radula and labial disc were made for light microscopy (LM) and scanning electron microscopy (SEM), by macerating the buccal bulb with $5 \% \mathrm{KOH}$. For LM the radula and labial disc were mounted in Hoyer's liquid, while for SEM, the radula was mounted in distilled water between two coverslips and the labial disc in water in a small container, frozen in liquid nitrogen and lyophilised; Thus the radula was perfectly stretched and the lip disc was not wrinkled, glued to the SEM stub with DHMF resin (dimethyl-hydantoin formaldehyde), sputter coated with gold-palladium on a Bio-Rad e5000 coated and examined under a LEO435VP SEM with Microanalysis (EDX, Oxford 300) Leica Microsystems (Cambridge, U. K.).

Spicule preparations: The study of the spicules and spicular skeletal arrangement presented numerous problems, as the traditional methods of isolation: $4 \% \mathrm{NaOH}, 4 \% \mathrm{KOH}$,
$5 \% \mathrm{NaClOH}$ and $\mathrm{H}_{2} \mathrm{O}_{2}$, resulted in spicules decay. Thus, alternative methods were used: $\mathrm{Cl}_{2} \mathrm{CH}_{4}, \mathrm{CaO}, 0$ '25\% trypsin, protease $\mathrm{K}$ at $15 \mathrm{ppm}$, natural bacterial decomposition in seawater and incineration of the organic matter in a muffle at $500^{\circ} \mathrm{C}$ for 48 hours, the latter being the one with which the best results were obtained. Spicule preparations for OM were mounted in Hoyer's liquid, synthetic resin and Canada balsam, while for SEM they were mounted on a circular glass coverslip glued with a carbon adhesive to the SEM stub, sputter coated with gold-palladium. The study of the skeletal arrangement was performed by $\mathrm{X}$-ray computed microtomography (Micro-CT Skyscan 1172).

Serial sectioning: Serial sections $15 \mu \mathrm{m}$ thick were taken from two specimens (Paratypes 4 and 15 and from parts of the dissection of paratypes 10 and 17) which were fixed in Bouin's fluid, decalcified with ethylenediaminotetraacetic acid (EDTA), embedded in paraffin, sectioned with a Microm HM310 rotary microtome and stained with Mallory's trichrome (GIL-Mansilla, et al. 2008).

Micro-CT: The study of the anatomical and skeletal structure was carried out using micro-computed tomography, the specimens used (Paratypes 6 and 16) were preserved in $70 \%$ ethanol. Subsequently, they were dehydrated in successive baths of $80 \%, 90 \%$ and $96 \%$ ethanol. The specimens were scanned with a Skyscan 1172 microtomograph.

Paratype 6 was scanned three times with the following treatments and parameters:

1.- The specimen was stained with $1 \%$ iodine in $96^{\circ}$ ethanol during one week before dehydration with hexamethyldisilazane (HMDS) for four hours, and subsequently air dried overnight (Alba-Tercedor \& Sanchez-Tocino, 2011; Faulwetter, et al. 2013; CANDÁs, et al. 2016). The following parameters were used: 55 $\mathrm{kv}, 165 \mu \mathrm{A}$, no filter and pixel size of $6.78 \mathrm{um}$. The sample was rotated $360^{\circ}$ and the projection images were obtained at $0.25^{\circ}$ intervals.

2.- The specimen was placed inside a closed polypropylene tube with a paper moistened with $96^{\circ} \mathrm{EtOH}$ at the bottom to maintain a moist atmosphere inside. The scanning parameters 
were: $55 \mathrm{kv}, 165 \mu \mathrm{A}$, no filter and pixel size of $13.57 \mathrm{um}$. The sample was rotated $360^{\circ}$ and the projection images were obtained at $0.30^{\circ}$ intervals.

3.- The specimen was submerged in $5.5 \%$ EDTA in $10 \%$ formaldehyde for four days. Then it was dehydrated in successive baths of $80 \%, 90 \%$ and $96 \%$ ethanol. Subsequently, it was stained again with $1 \%$ iodine in $96^{\circ}$ ethanol during five days before dehydration with HMDS for four hours, prior to scanning. Scanning was performed at: $55 \mathrm{kv}, 165 \mu \mathrm{A}$, no filter and pixel size of $13.57 \mathrm{um}$. The sample was rotated $360^{\circ}$ and the projection images were obtained at $0.20^{\circ}$ intervals.

Paratype 16 was scanned twice with the following treatments and parameters:

1.- The specimen was stained with $1 \%$ iodine in $96^{\circ}$ ethanol during one week before scanning. It was placed inside a closed polypropylene tube with a paper moistened with $96^{\circ}$ ethanol at the bottom to maintain a moist atmosphere inside. The scanning parameters were as follows: $60 \mathrm{kv}, 167 \mu \mathrm{A}$, no filter and pixel size of $13.57 \mathrm{um}$. It was rotated $360^{\circ}$ and the projection images were obtained at $0.30^{\circ}$ intervals.

2.- The specimen was stained with $1 \%$ iodine in $96^{\circ}$ ethanol during two weeks before scanning. It was placed inside a closed polypropylene tube with a paper moistened with $96^{\circ}$ ethanol at the bottom to maintain a moist atmosphere inside. The scanning parameters were as follows: $60 \mathrm{kv}, 167 \mu \mathrm{A}$, no filter and pixel size of $13.57 \mathrm{um}$. It was rotated $360^{\circ}$ and the projection images were obtained at $0.25^{\circ}$ intervals.

The images were reconstructed with the NRecon software (Bruker, Belgium) and the obtained sections were cleaned with the CTAnalyzer software (Bruker, Belgium). The software CTVox and DataViewer (Bruker, Belgium) were used for the correct visualization of the data. After studying the obtained sections, $3 \mathrm{D}$ reconstruction was carried out using the program AVIZO 6.4 (Thermo Fisher Scientific) which allows three-dimensional anatomical models to be obtained from the two-dimensional images of the sections. After choosing the pixel size and loading the cross-sectional images into AVIZO, they were aligned, drawing the different structures manually in the form of overlapping colour layers and then smoothed, to eliminate imperfections in order to obtain a sharp three-dimensional image.

DNA analysis: For molecular analysis, a fragment of the foot of Paratype 20 was soaked in water for 30 minutes before genomic DNA extraction with DNeasy Blood \& Tissue Kit (Qiagen, Germany). A 657 base pair region from the 5' end of mitochondrial coxl ("barcode region") was amplified with standard LCO / HCO primers (Folmer, et al. 1994). Amplification was performed with BiolineMyTaq and the following cycling: $94^{\circ} \mathrm{C}$ for 2 min $30 \mathrm{sec}, 40$ cycles of $94^{\circ} \mathrm{C}$ for $30 \mathrm{~s}, 47^{\circ} \mathrm{C}$ for $45 \mathrm{~s}$ and $72^{\circ} \mathrm{C}$ for $1 \mathrm{~min} 15 \mathrm{sec}$, and final extension of $72^{\circ} \mathrm{C}$ for $10 \mathrm{~min}$. PCR products were sent to StabVida (Portugal) for purification with magnetic beads and sequencing in both directions using ABI 3730xl DNA Analyzer. Sequence chromatograms were assembled and manually edited using Geneious 5.6.

A total of 177 cox 1-5' sequences within the genera Doris, Archidoris and Austrodoris were downloaded from GenBank in December 2020. The following species were represented, according to GenBank identification: 1 sequence of Archidoris montereyensis, 1 sequence of Archidoris pseudoargus, 1 sequence of Archidoris wellingtonensis, 93 sequences of Austrodoris kerguelenensis, 64 sequences of Doris kerguelenensis; 9 sequences of Doris montereyensis, 1 sequence of Doris nobilis, 6 sequences of Doris pseudoargus, 1 sequence of Doris sp. (this sequence was discarded in further analysis as it was not identified to species level). The full list of downloaded sequences is provided in Supplementary material Appendix 1. Unique haplotypes were identified $(n=132$; including the barcode sequence of Doris adrianae sp. nov.) and an alignment of $627 \mathrm{bp}$ was produced with Muscle in Geneious 5.6 after sequence trimming. One sequence per species (according to GenBank identity) was selected and an uncorrected pairwise identity (i.e., proportion of identical sites) was computed as a distance matrix in 
Geneious 5.6. This preliminary analysis confirmed that Archidoris, Austrodoris and Doris were synonymous genera. Thus, one sequence per non-synonimous species of Doris as well as an outgroup sequence (Hexabranchus sp., GenBank MN224071.1) were included in a phylogenetic tree run in Beast2 2.6 (BOUCKAERT et al. 2019). Model priors were set in BEAUti as a $\mathrm{GTR}+\mathrm{G}+\mathrm{I}$ and uncorrelated relaxed clock with $\mathrm{mcmc}=10000000$ and log every 1 000. In TreeAnnotator, 5000 (50\%) trees were discarded and a maximum clade credibility tree with median heights was built.

\section{RESULTS}

Class Gasteropoda Cuvier, 1795

Subclass Heterobranchia Burmeister, 1837

Orden Nudibranchia Cuvier, 1814 in Blainville, 1814

Suborden Doridina Bouchet et al, 2017

Superfamily Doridoidea Rafinesque, 1815

Family Dorididae Rafinesque, 1815

Genus Doris Linnaeus, 1758

Type species: Doris verrucosa Linnaeus, 1758, by subsequent designation: BoucheT \& VALDÉS (2000).

\section{Doris adrianae Urgorri \& Señarís sp. nov.}

http://zoobank.org/urn:1sid:zoobank.org:pub:51C800B8-6F45-4F56-8E68-ED-

\section{D53ECF248}

Diagnosis: Oval-shaped and orange-yellow in colour with fine black dorsal stippling, denser in the mid-lateral areas, $32-76 \mathrm{~mm}$ long and 18-55 $\mathrm{mm}$ wide. Dorsum covered with rounded tubercles of various sizes, slightly pointed, with a rough surface and a small basal stalk. Lamellar rhinophores and 7-8 tripinnate branchial leaves, surrounded at their base by wide sheaths with small tubercles on their surface. Foot orange, frontally bilaminate without notch. Head with two lateral oral lobes and without tentacles. Radular formula 0:33-53:3-4 x 38-50. Rachidian tooth absent, lateral teeth simple and curved with prominent ridge, with first central lateral teeth strongly curved and marginal teeth with plumose edge. Labial disc peltate in shape with soft rugosities.
Gastric caecum near the opening to the digestive gland. Reproductive system triaulic, ampulla long, tubular and thick, penis fusiform and unarmed, prostate large and granular in appearance. Vagina short and wide, bursa copulatrix large and oval, three times larger than the oval seminal receptacle. Vestibular gland at the end of the distal oviduct, near its opening in the genital atrium.

Derivatio nominis. The species is dedicated to Adriana Álvarez Urgorri, granddaughter of the senior author.

Type locality: Ría de Ferrol (Galicia, NW Iberian Peninsula): Punta Fornelos ( $43^{\circ} 28^{\prime}$ $02 " \mathrm{~N}$; $008^{\circ} 18^{\prime} 50$ " W) all animals (Holotype and Paratype 1-16) were collected between 16 and $20 \mathrm{~m}$ deep on rocky bottoms with muddy sand sedimentation; Castelo de San Felipe (43 $27^{\prime} 47^{\prime \prime} \mathrm{N}$; 008 $16^{\circ}$ '57" W) all animals (Paratype 17-20) were collected between 11 and $18 \mathrm{~m}$ deep on rocky bottoms with sand on the surface; Punta Barbeira ( $43^{\circ} 28^{\prime} 3.19^{\prime \prime}$ $\mathrm{N} ; 008^{\circ} 19^{\prime} 11.52^{\prime}$ W) all animals (Paratype 21-22) were collected between 12 and $18 \mathrm{~m}$ deep on rocky bottoms with muddy sand sedimentation (Fig. 1).

Other localities: 01010204: 3 specimens and 01250404: 1 specimen in O Grelle (Ría da Coruña, NW Iberian Peninsula) (43 $22^{\prime}$ 53 " N; $\left.008^{\circ} 23^{\prime} 30^{\prime \prime} \mathrm{W}\right)$. The 4 specimens were not collected but were photographed in situ, on rocky bottoms with small red algae and incrusting sponges at a depth between 12$16 \mathrm{~m}$. 01141190: 1 specimen $50 \mathrm{~mm}$ long at Sálvora (Ría de Arousa, NW Iberian Peninsula): (42 $25^{\prime} 38^{\prime} " \mathrm{~N}$; $\left.009^{\circ} 0.478^{\prime} \mathrm{W}\right)$. It was collected on maërl bottoms with Veretillum cynomorium (Pallas, 1766) and Pteroeides griseum (Bohadsch, 1761), at a depth of 60 $\mathrm{m}$. Orig. fixative and preserved in $70 \% \mathrm{EtOH}$ neutralized with Borax.

\section{TYPE MATERIAL AND DEPOSITION:}

Holotype: 02020892 (MHN-USC 10119). 1 specimen, complete, $65 \mathrm{~mm}$ long in vivo. Punta Fornelos (Ría de Ferrol) 02/08/1992. Orig. fixed in Bouin's solution and preserved in $70 \% \mathrm{EtOH}$ neutralized with Borax. 
Paratype 1: 01060786-01 (MHN-USC 10119-01). 1 specimen, dissected, $50 \mathrm{~mm}$ long in vivo. Punta Fornelos (Ría de Ferrol) 06/07/1986. Orig. fixed in Bouin's solution and preserved in $70 \% \mathrm{EtOH}$ neutralized with Borax.

Paratype 2: 01060786-02 (MHN-USC 10119-02). 1 specimen, complete, $40 \mathrm{~mm}$ long in vivo. Punta Fornelos (Ría de Ferrol) $06 / 07 / 1986$. Orig. fixed in Bouin's solution and preserved in $70 \% \mathrm{EtOH}$ neutralized with Borax.

Paratype 3: 01160591 (MCUC.2021.1.1). 1 specimen, complete, $32 \mathrm{~mm}$ long in vivo. Punta Fornelos (Ría de Ferrol) 16/05/1991. Orig. fixed in Bouin's solution and preserved in $70 \% \mathrm{EtOH}$ neutralized with Borax.

Paratype 4: 02030592 (MHN-USC 1011904). 1 specimen, histological sections, $48 \mathrm{~mm}$ long in vivo. Punta Fornelos (Ría de Ferrol) 03/05/1992. Orig. fixed in Bouin's solution and preserved in $70 \%$ EtOH neutralized with Borax. The anterior and posterior portions of the specimen are still embedded in paraffin block.

Paratype 5: 02300596(ZSM Mol 20210004). 1 specimen, complete, $37 \mathrm{~mm}$ long in vivo. Punta Fornelos (Ría de Ferrol) 30/05/1996. Orig. fixed and preserved in $70 \%$ EtOH neutralized with Borax.

Paratype 6: 05050896 (MHN-USC 1011906). 1 specimen, complete, $40 \mathrm{~mm}$ long in vivo, scanned in the Micro-CT. Punta Fornelos (Ría de Ferrol) 05/08/1996. Orig. fixed and preserved in $70 \% \mathrm{EtOH}$ neutralized with Borax.

Paratype 7: 05130597-01 (MHN-USC 10119-07). 1 specimen, dissected, $60 \mathrm{~mm}$ long in vivo. Punta Fornelos (Ría de Ferrol) $13 / 05 / 1997$. Orig. fixed and preserved in $70 \%$ EtOH neutralized with Borax.

Paratype 8: 05130597-02 (MNHNIM-2012-25572). 1 specimen, complete, in $45 \mathrm{~mm}$ long in vivo. Punta Fornelos (Ría de Ferrol) 13/05/1997. Orig. fixed and preserved in $70 \% \mathrm{EtOH}$ neutralized with Borax.

Paratype 9:01080598-01 (MCUC.2021.1.2). 1 specimen, complete, $50 \mathrm{~mm}$ long in vivo. Punta Fornelos (Ría de Ferrol) 08/05/1998. Orig. fixed and preserved in 70\% EtOH neutralized with Borax.
Paratype 10: 01080598-02 (MHN-USC 10119-10). 1 specimen, dissected, $45 \mathrm{~mm}$ long in vivo. Punta Fornelos (Ría de Ferrol) $08 / 05 / 1998$. Orig. fixed and preserved in $70 \%$ EtOH neutralized with Borax.

Paratype 11: 02101199 (MHN-USC 1011911). 1 specimen, complete, $40 \mathrm{~mm}$ long in vivo. Punta Fornelos (Ría de Ferrol) 10/11/1999. Orig. fixed in Bouin's solution and preserved in $70 \% \mathrm{EtOH}$ neutralized with Borax.

Paratype 12: 01240505 (MHN-USC 1011912). 1 specimen, dissected, $40 \mathrm{~mm}$ long in vivo. Punta Fornelos (Ría de Ferrol) 24/05/2005. Orig. fixed and preserved in 100\% EtOH.

Paratype 13: 03220705 (MHN-USC 1011913). 1 specimen, complete, $40 \mathrm{~mm}$ long in vivo. Punta Fornelos (Ría de Ferrol) 22/07/2005. Orig. fixed and preserved in 100\% EtOH.

Paratype 14: 04190805 (MHN-USC 1011914). 1 specimen, dissected, $50 \mathrm{~mm}$ long in vivo. Punta Fornelos (Ría de Ferrol) 19/08/2005. Orig. fixed and preserved in $70 \% \mathrm{EtOH}$ neutralized with Borax.

Paratype 15: 03040106 (MHN-USC 1011915). 1 specimen, histological sections, $51 \mathrm{~mm}$ long in vivo. Punta Fornelos (Ría de Ferrol) 04/01/2006. Orig. fixed in Bouin's solution and preserved in $70 \%$ EtOH neutralized with Borax.

Paratype 16: 01240510 (MHN-USC 1011916). 1 specimen, complete, $41 \mathrm{~mm}$ long in vivo, scanned in the Micro-CT. Punta Fornelos (Ría de Ferrol) 24/05/2010. Orig. fixed in Bouin's solution and preserved in 70\% EtOH neutralized with Borax.

Paratype 17: 01290806-01 (MHN-USC 10119-17). 1 specimen, dissected and cut in histological sections, $71 \mathrm{~mm}$ long in vivo. Castelo de San Felipe (Ría de Ferrol) 29/08/2006. Orig. fixed and preserved in $100 \% \mathrm{EtOH}$.

Paratype 18: 01290806-02 (MHN-USC 10119-18). 1 specimen, dissected, $63 \mathrm{~mm}$ long in vivo. Castelo de San Felipe (Ría de Ferrol) $29 / 08 / 2006$. Orig. fixed and preserved in 100\% EtOH. Spawning sample for DNA.

Paratype 19: 01220807-01 (MHN-USC 10119-19). 1 specimen, complete, $76 \mathrm{~mm}$ long in vivo. Castelo de San Felipe (Ría de Ferrol) $22 / 08 / 2007$. Orig. fixed and preserved in $100 \%$ $\mathrm{EtOH}$. 
Paratype 20: 01220807-02 (MHN-USC 10119-20). 1 specimen, complete, $55 \mathrm{~mm}$ long in vivo. Castelo de San Felipe (Ría de Ferrol) $22 / 08 / 2007$. Orig. fixed and preserved in 100\% EtOH. Spawning sample for DNA.

Paratype 21: 01020519-01 (MHN-USC 10119-21). 1 specimen, complete, $40 \mathrm{~mm}$ long in vivo. Punta Barbeira (Ría de Ferrol) 02/05/2019. Orig. fixed in Bouin's solution and preserved in $70 \%$ EtOH neutralized with Borax.

Paratype 22: 01020519-02 (MHN-USC 10119-22). 1 specimen, complete, $55 \mathrm{~mm}$ long in vivo. Punta Barbeira (Ría de Ferrol) 02/05/2019. Orig. fixed in Bouin's solution and preserved in $70 \%$ EtOH neutralized with Borax.

The Holotype and the Paratypes 1, 2, 4, 6, 7, 10-20 have been deposited at the Museo de Historia Natural of the Universidade de Santiago de Compostela, Galicia, Spain (MHNUSC). Paratypes 3 and 9 have been deposited at the Museu da Ciência da Universidade de Coimbra, Portugal (MCUC), Paratype 5 at the Zoologische Staatssammlung München, Germany (ZSM) and Paratype 8 at the Museum National d'Histoire Naturelle, Paris, France (MNHN).

Faecal pellets, spawning and preparations: Samples of faecal pellets of the Holotype and Paratypes $4,6,8,9,13,17,18,19,20,21$ and 22 are preserved in $70 \% \mathrm{EtOH}$ neutralized with Borax. One spawning collected at sea with Paratypes 17 and 18 and several egg masses made in the laboratory aquarium, larvae and eggs of Paratypes 17, 18, 21 and 22 are also preserved. In addition, 92 SEM preparations are preserved of: radula, spicules, labial disc, eggs, larval shell, faecal pellets and spicules of Polymastia boletiformis (Lamarck, 1815) and 79 LM preparations: radula, spicules of the foot, dorsal and ventral mantle, tubercles and rhinophores, faecal pellets and spicules of the sponge Polymastia boletiformis (Lamarck, 1815). Also preserved are 383 preparations of histological sections of Paratype 4, 941 preparations of histological sections of Paratype 15, 81 preparations of histological sections of the genital system of Paratype 17 and 6 preparations of histological sections of the penis of Paratype 10. All this material has also been deposited at the Museo de Historia Natural of the Universidade de Santiago de Compostela, Galicia, Spain (MHN-USC 10119).

\section{DESCRIPTION}

\section{External Anatomy}

Habitus: The general colour of live animals varies from yellow to yellow-orange, although yellow specimens predominate (Fig. 2). The entire dorsal surface is finely dotted with black dots, which are only visible under the stereoscopic microscope. These dots increase their density in the mid-lateral areas of the notum, forming two somewhat darker bands running from the rhinophores to the gill (Figs. 2E,F). The outline of the mantle is oval to oblong, dorsally strongly convex, elevated, with a very hard consistency covering the whole animal, even when it is moving; the semicircular metapodium never protrudes (Figs. 2G,H). It possesses two small eyes, located between the two lobes of the blood gland, but they are not visible externally (Figs. 2A-G, 8B). The size of collected specimens varies between 32 and $76 \mathrm{~mm}$ in length and 18 and $55 \mathrm{~mm}$ in width, although the most frequent size fluctuates between $40-55 \mathrm{~mm}$ in length and $30-40 \mathrm{~mm}$ in width; the length/width ratio ranges from 1.3 to 1.8 .

The entire dorsum is covered with rounded, slightly pointed, rough-surfaced tubercles with a small, broad basal stalk (Figs. 2A-G, 3G,H). In lateral view the tubercles have a conical appearance (Fig. 3H) and their colour is the same as that of the mantle with the same black stippling. The rough surface of the tubercles has an orange-peel appearance. The lattice of radial spicules giving shape to the tubercle can be seen through transparency, with the tips of the spicules directed towards the surface but not protruding outwards.

The tubercles range in size from large to very small, with various sizes in between so they cannot be grouped into any particular category, and with no consistent distribution. All sizes are present throughout the dorsum of the mantle, although the larger ones are much more abundant in the central part of 


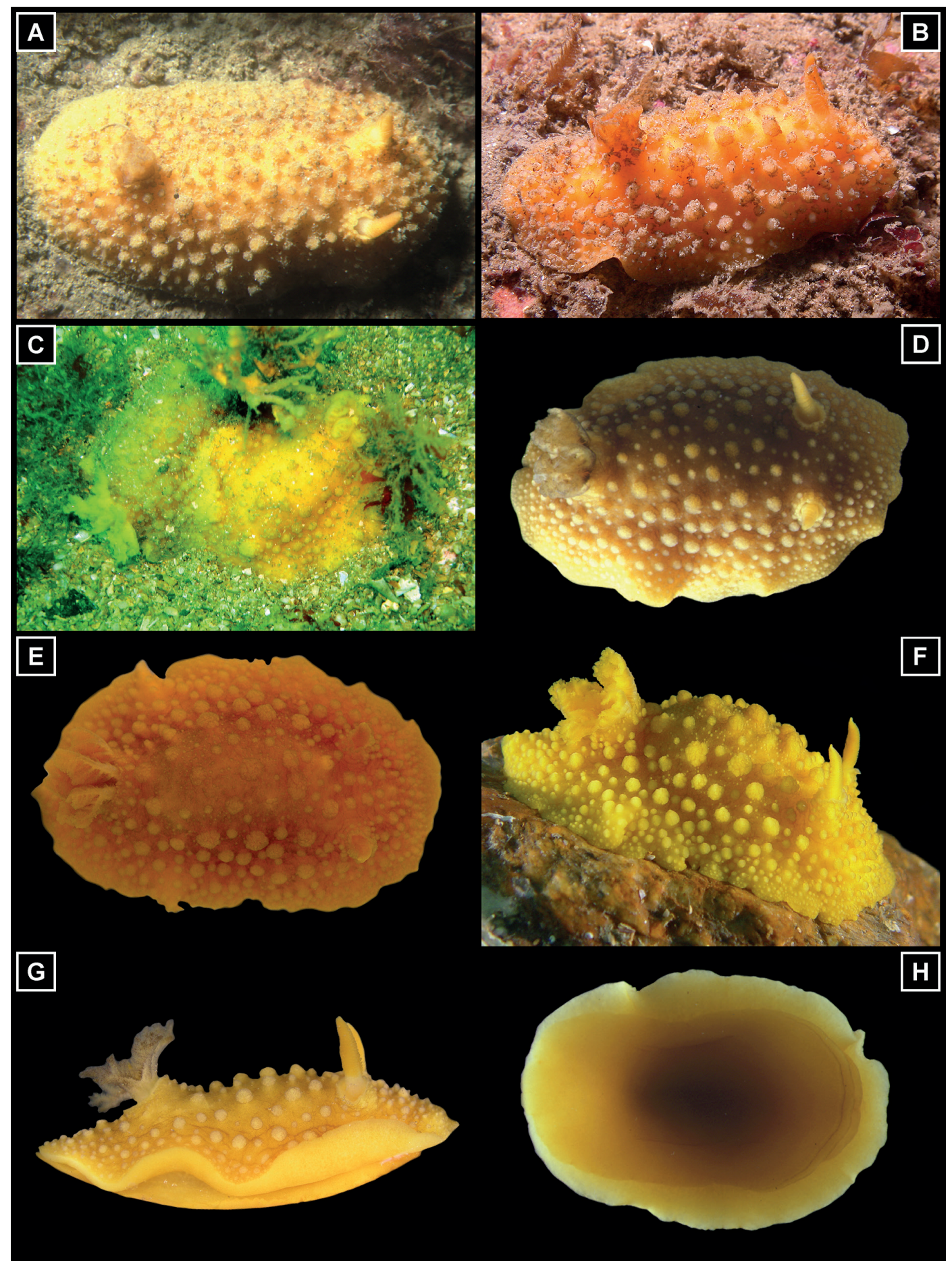

Figure 2. Doris adrianae sp. nov. Habitus and external appearance in vivo. A: Holotype 02020892, dorsal view in habitat, $65 \mathrm{~mm}$. B: O Grelle 01250404, lateral view in habitat, $40 \mathrm{~mm}$. C: Paratypes 17 and 18 01290806, top view of the two specimens copulating in habitat, 71-63 mm. D: Paratype 2, 01060786, dorsal view in aquarium, $40 \mathrm{~mm}$. E: Paratype 19, 01220807, dorsal view in aquarium, $76 \mathrm{~mm}$. F: Paratype 19, 01220807, lateral view in aquarium, $76 \mathrm{~mm}$. G: Paratype 15, 03040106, lateral view in aquarium, $51 \mathrm{~mm}$. H: Paratype 2, 01060786 , ventral view in aquarium, $40 \mathrm{~mm}$.

Figura 2. Doris adrianae sp. nov. Habitus y aspecto externo in vivo. A: Holotipo 02020892 , vista dorsal en hábitat, $65 \mathrm{~mm}$. B: O Grelle 01250404, vista lateral en hábitat, $40 \mathrm{~mm}$. C: Paratipos 17 y 1801290806 , vista superior de dos ejemplares copulando en hábitat, 71-63 mm. D: Paratipo 2, 01060786, vista dorsal en acuario, 40 mm. E: Paratipo 19, 01220807, vista dorsal en acuario, 76 mm. F: Paratipo 19, 01220807, vista lateral en acuario, 76 mm. G: Paratipo 15, 03040106, vista lateral en acuario, $51 \mathrm{~mm}$. H: Paratipo 2, 01060786, vista ventral en acuario, $40 \mathrm{~mm}$. 


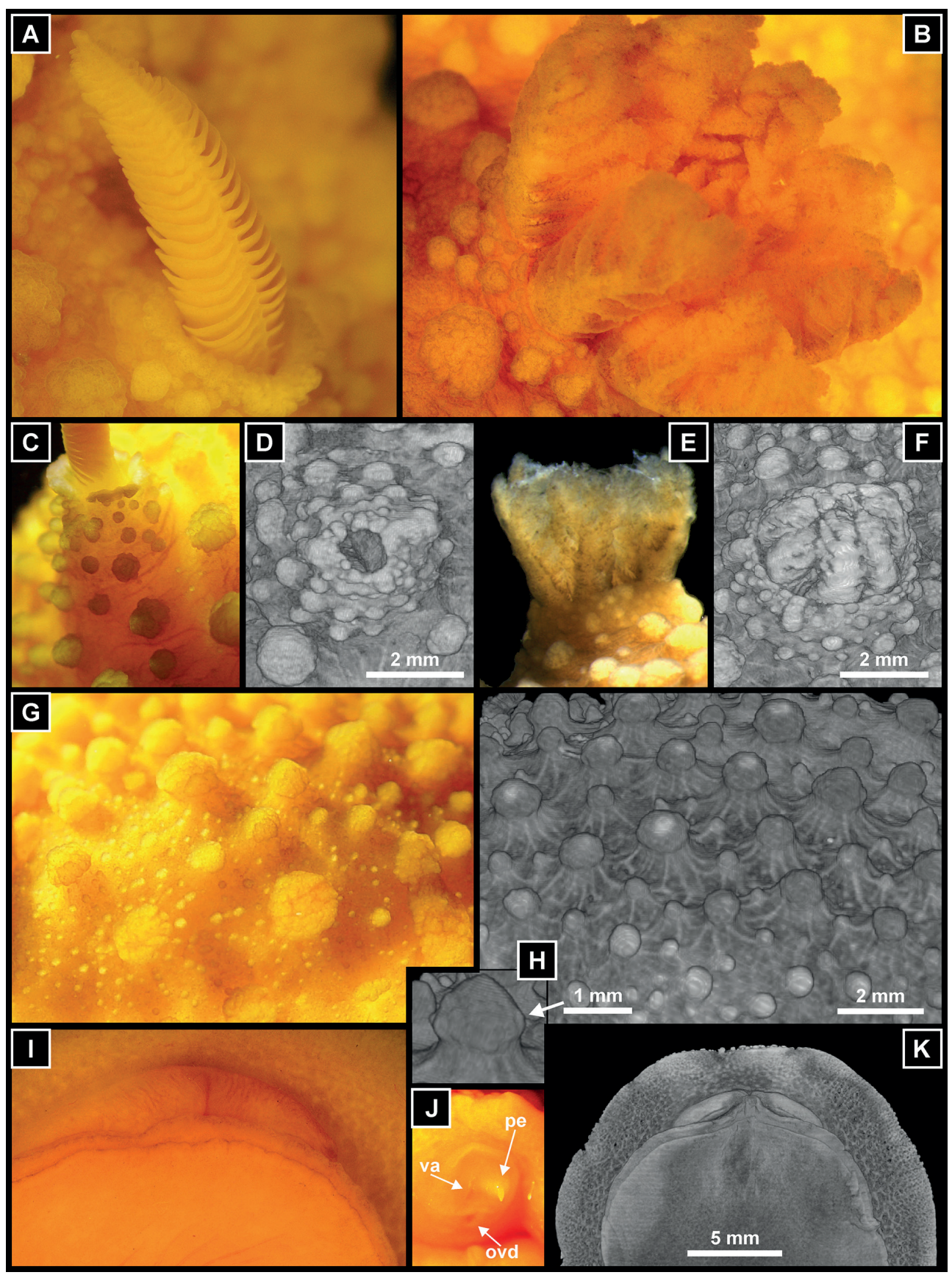

Figure 3. Doris adrianae sp. nov. Details of the external appearance. A: Rhinophore in vivo, Paratype 19, 01220807_01, 76 mm. B: Branchial leaves, Paratype 19, 01220807-01, 76 mm. C: Rhinophoral sheath, Paratype 19, 01220807-01, 76 mm. D: Rhinophoral sheath, Paratype 16, 01240510, $41 \mathrm{~mm}$. E: Branchial leaves and branchial sheath, Paratype 2, 0106078602, 40 mm. F: Branchial sheath, Paratype 16, 01240510, $41 \mathrm{~mm}$. G: Dorsal tubercles, Paratype 19, 01220807-01, 76 mm. H: Dorsal tubercles and detail of a tubercle, Paratype 6, 05050896, $40 \mathrm{~mm}$. I: Oral lobes and anterior edge of bilaminated foot, Paratype 15, 03040106, 51 mm. J: External genital atrium, Paratype 19, 01220807-01, 76 mm. K: Ventral view of the anterior third of the animal, Paratype, 16 01240510, $41 \mathrm{~mm}$. (A,B,C,E,G,I,J in vivo. D,F,H,K Micro-CT).

Figura 3. Doris adrianae sp. nov. Detalles del aspecto externo. A: Rinóforo in vivo, Paratipo 19, 01220807-01, 76 mm. B: Branquias, Paratipo 19, 01220807-01, 76 mm. C: Vaina rinofórica, Paratipo 19, 01220807-01, 76 mm. D: Vaina rinofórica, Paratipo 16, 01240510, $41 \mathrm{~mm}$. E: Branquias y vaina branquial, Paratipo 2, 01060786-02, $40 \mathrm{~mm}$. F: Vaina branquial, Paratipo 16, 01240510, 41 mm. G: Tubérculos dorsales, Paratipo 19, 01220807-01, 76 mm. H: Tubérculos dorsales y detalle de un tubérculo, Paratipo 6, 05050896, $40 \mathrm{~mm}$. I: Lóbulos orales y borde anterior del pie bilaminado, Paratipo 15, 03040106, $51 \mathrm{~mm}$. J: Atrio genital externo, Paratipo 19, 01220807-01, $76 \mathrm{~mm}$. K: Vista ventral del tercio anterior del animal, Paratipo, 16 01240510, 41 mm. (A,B,C,E,G,I,J in vivo. D,F,H,K Micro-CT). 
the notum and in the two darker lateral bands (black dots) from the rhinophores to the gills. In general, the size of the large tubercles decreases towards the edges of the mantle, where the smaller ones are much more abundant (Figs. 2A,B,D,F,G, 3G,H). Very small tubercles are scattered over the entire surface of the notum, including the rhinophoral sheaths and gill sheath, being slightly more abundant on the dorsal half and on the edge of the notum (Figs. 2C-H).

The rhinophores are elongate, narrow, slightly curved backwards with 29-34 lamellae in the upper two thirds of their length and with a slightly truncated conical basal stalk occupying the lower third (Figs. 2F,G, 3A). Yellow lamellae with slight black stippling, with the spicules arranged radially; they are arched and arranged alternately to right and left in a zigzagging frontal line. The tip of the rhinophore is a small truncated cylinder and the rhinophore stalk is white.

Gill with 6-8 tripinnate leaves, which appear to be bipinnate, as the tertiary branching is only visible at high magnification (Figs. 2A-G, $3 \mathrm{~B}, \mathrm{E})$. In some specimens it has been observed that the two posterior leaves on each side each arise from a single basal bifurcation. The colour of the gill is quite variable, as in most specimens they is yellow to yellow-orange like the mantle (Figs. 2F, 3B), while in others it is whitish (Figs. 2G, 3E). All leaves show black dots like those on the dorsum, less dense on the rachis, but the rest of the leaf has different densities that give it a more or less dark colour, especially on the whitish leaves (Figs. $2 \mathrm{G}, 3 \mathrm{~B}, \mathrm{E})$. The anus opens at the end of the anal papilla in the centre of the gills and is yellowish with few dots.

The rhinophoral and branchial sheaths are complete, raised, yellow with small to medium-sized tubercles on the edge (Figs. 3AF). The two sheaths are of the same height, but the branchial sheath is much wider; the rhinophoral sheath may be as long as onethird the length of the rhinophore. When the rhinophores and gill retract, the sheaths close completely, bringing the edges closer together like a sphincter (Figs. 3C-F). The rhinophores are retracted by the action of three pairs of small muscles inserted at the base of the stalk and diverging forwards, medially and posteriorly; the gill is also retracted by the action of three pairs of muscles, but of larger size than those of the rhinophores.

The mantle is ventrally slightly paler in colour than the dorsum, being the dense net of spicules visible through transparency (Figs. $2 \mathrm{G}-\mathrm{H})$. The foot, head and epipodium are more orange in colour than the rest of the animal, which is more yellow, with very few black dots. On the head, on the sides of the mouth, there are two flattened lobes without oral tentacles. The anterior edge of the foot is complete, without any notch and grooved on the anterior quarter, the upper lamella protruding more than the lower one (Figs. $2 \mathrm{H}, 3 \mathrm{I}, \mathrm{K})$. At rest and during movement the foot does not protrude from the edge of the mantle. However, very exceptionally, when the movement is very fast the posterior part of the metapodium protrudes slightly (Figs. 2G,H).

\section{Internal Anatomy}

Skeletal structure: Doris adrianae sp. nov. has numerous calcareous spicules throughout its body, except in the visceral organs, which are arranged in a dense network, forming an armoured skeletal structure (Fig. 6A). This gives the animal a very compact consistency, clearly perceptible to the touch when specimens are collected.

Doris adrianae sp. nov. has two types of spicules, some monoaxonic fusiform, irregular, elongated and with blunt ends (Fig. 4A), ranging in size from $70-770 \mu \mathrm{m}$ in length, with sizes between 111-320 $\mu \mathrm{m}$ being more abundant (Fig. 5A). A second type of spicules are globose spherules, practically spherical, with a smooth surface and ranging in size from 5-15 $\mu \mathrm{m}$ in diameter (Fig. 4B).

Fusiform spicules are more or less circular but irregular in section, with the thickest part located more or less in the centre of the spicule and with blunt ends, almost never acuminate. Although they are generally rectilinear, almost all show some degree of greater or lesser curvature, some being very curved and even with one of the ends bent at $45^{\circ}$ (Fig. 4A). Their 

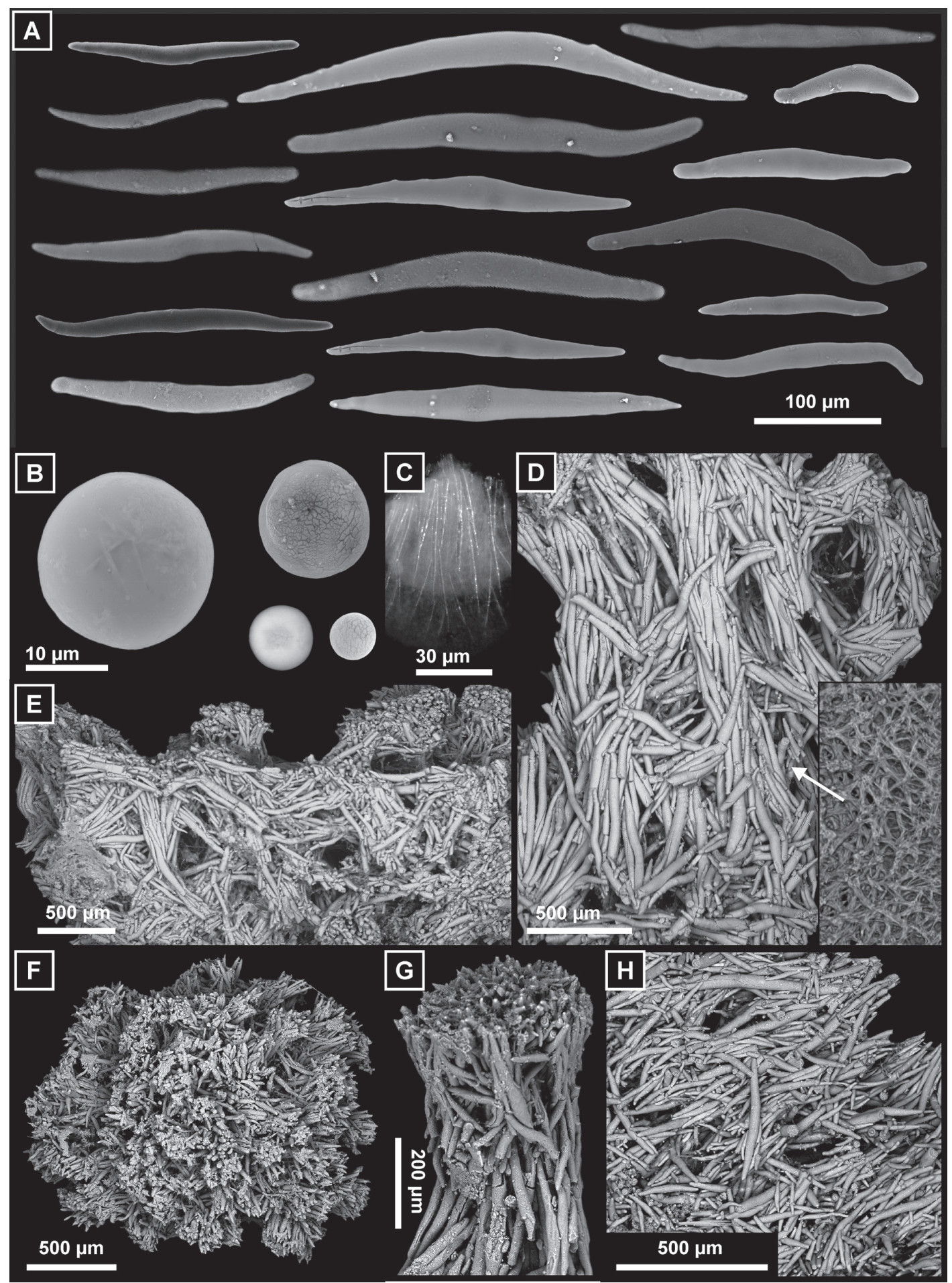

Figure 4. Doris adrianae sp. nov. Skeletal structure. A: Different shapes and sizes of the fusiform spicules. B: Spherules. C: Spicules in a rhinophore lamina, Paratype 10 01080598-02, 45 mm. D: Skeletal structure of ventral mantle. E: Sagittal skeletal structure of lateral mantle. F: Radial spicular arrangement in a tubercle. G: Spicular arrangement of tubercle stalk. H: Spicular arrangement of foot. (D-H: Paratype 16 01240510, 41 mm). (A,B,D,E,F,G,H SEM. C LM).

Figura 4. Doris adrianae sp. nov. Estructura esquelética. A: Diferentes formas y tamaños de las espículas fusiformes. B: Esférulas. C: Espículas en una lámina del rinóforo, Paratipo 10 01080598-02, 45 mm. D: Estructura esquelética del manto ventral. E: Estructura esquelética sagital del manto lateral. F: Disposición espicular radial en un tubérculo. G: Disposición espicular del tallo del tubérculo. H: Disposición espicular del pie. (D-H: Paratipo $1601240510,41 \mathrm{~mm}$ ). (A,B,D,E,F,G,H SEM. C MO). 

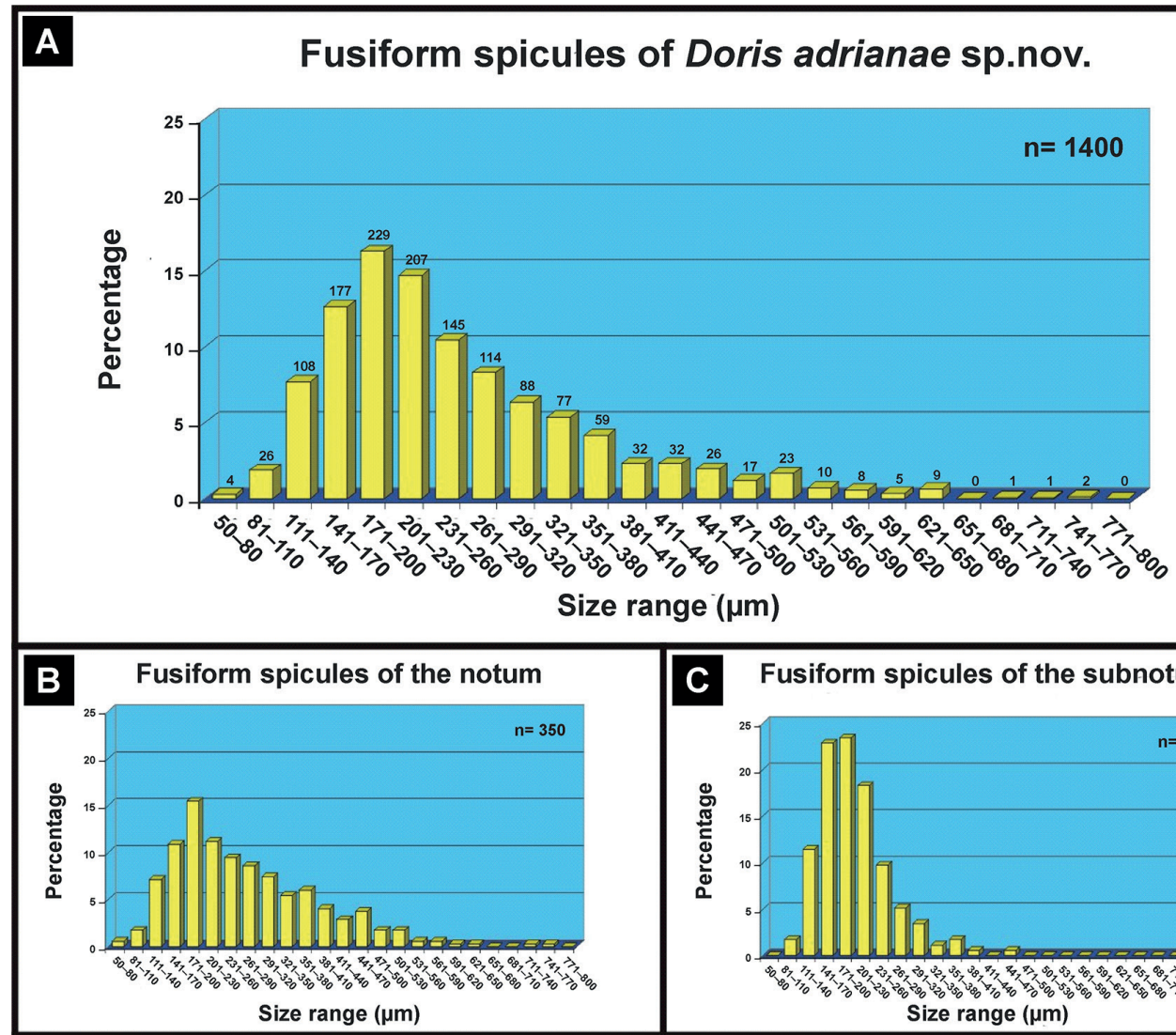

C Fusiform spicules of the subnotum
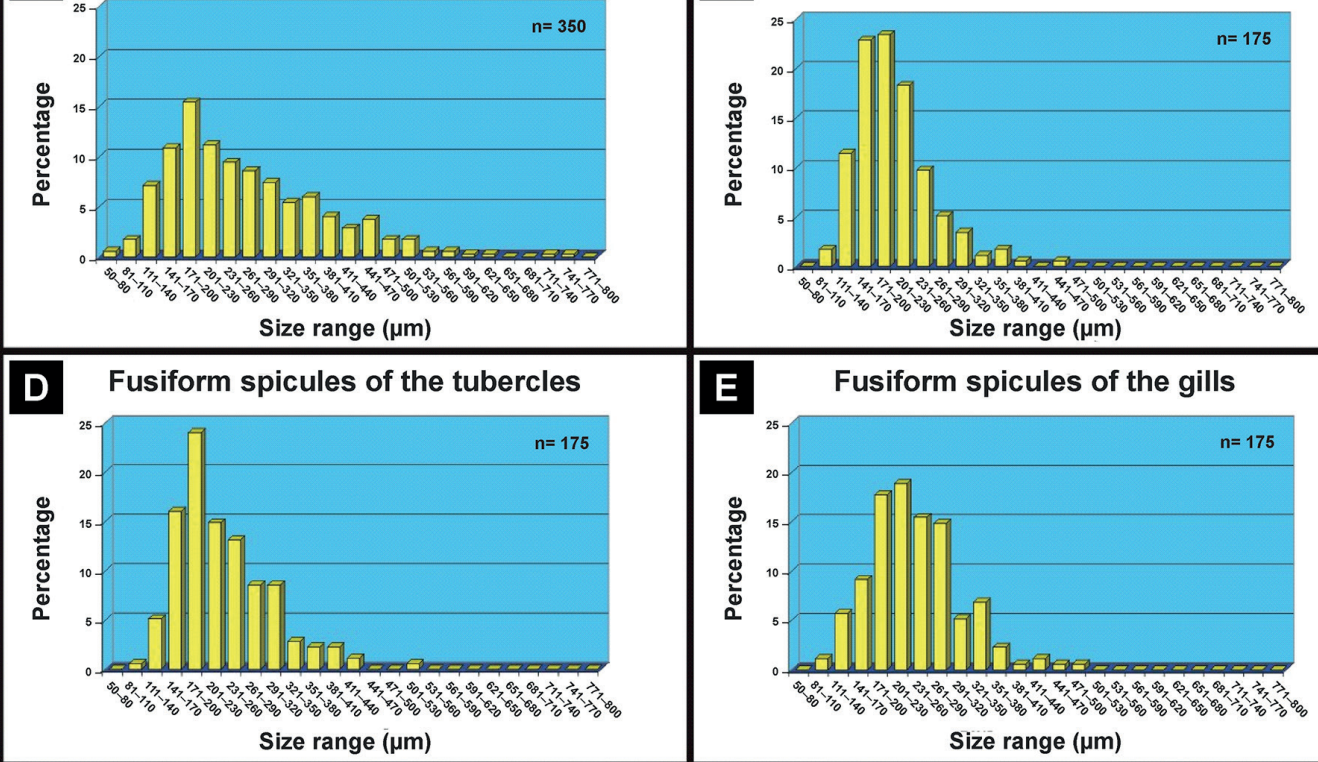

\section{E Fusiform spicules of the gills}

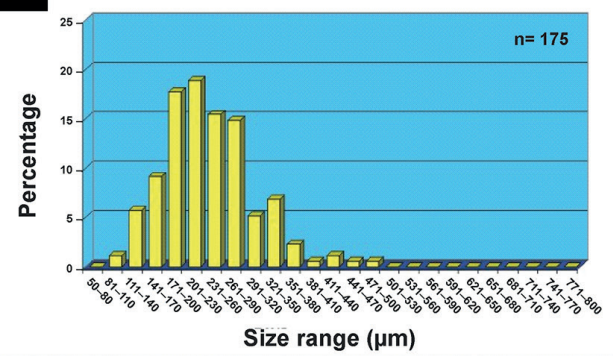

\section{$\mathbf{F}$}

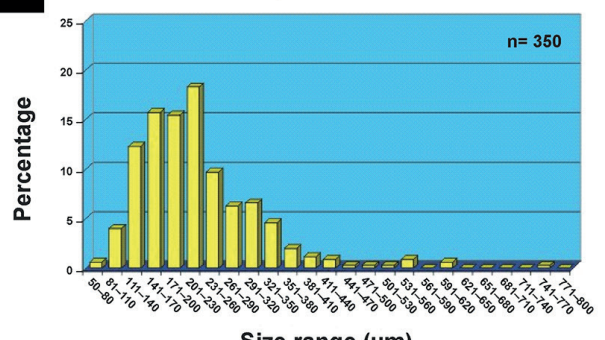

G Fusiform spicules of the rhinophores

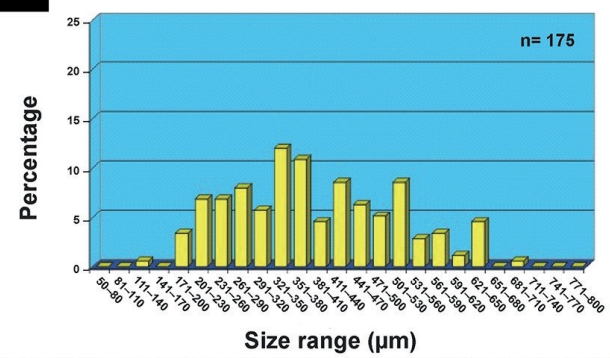

Figure 5. Doris adrianae sp. nov. Size distribution of fusiform spicules. A: Lengths of total fusiform spicules $(\mathrm{n}=1400)$. B: Lengths of spicules of notum $(n=350)$. C. Lengths of spicules of subnotum $(n=175)$. D: Lengths of spicules of tubercles $(\mathrm{n}=175)$. E: Lengths of gill spicules $(\mathrm{n}=175)$. F: Lengths of foot spicules $(\mathrm{n}=350)$. G: Lengths of rhinophore spicules $(\mathrm{n}=175)$.

Figura 5. Doris adrianae sp. nov. Distribución de tamaños de las espículas fusiformes. A: Longitudes de las espículas fusiformes totales $(\mathrm{n}=1400)$. B: Longitudes de las espículas del notum $(\mathrm{n}=350)$. C. Longitudes de las espículas del subnotum $(\mathrm{n}=175)$. D: Longitudes de las espículas de los tubérculos $(\mathrm{n}=175)$. E: Longitudes de las espículas de las branquias $(\mathrm{n}=175)$. F: Longitudes de las espículas del pie $(\mathrm{n}=350)$. G: Longitudes de las espículas del rinóforo $(\mathrm{n}=175)$. 
surface is smooth, without extensions or protuberances; however, some spicules, especially the larger ones, may have a series of small, irregularly distributed protuberances at their apices (Fig. 4A).

SEM microanalysis of the fusiform spicules showed that they are composed of: $\mathrm{Mg}, \mathrm{Ca}, \mathrm{O}$, $\mathrm{C}$ and $\mathrm{F}$, elements that crystallise amorphously, although when subjected to $400{ }^{\circ} \mathrm{C}$ they recrystallise in the form of calcite, brucite, fluorite and fluorapatite. SEM microanalysis of the spherules showed that they are composed of $\mathrm{Ca}, \mathrm{O}$ and $\mathrm{C}$.

Fusiform spicules are found on the mantle (notum and subnotum), tubercles, gills, foot and rhinophores. Their size distribution is more or less similar to all others, except for the rhinophore spicules which show a different size distribution (Figs. 5A-G). Globularshaped spherules are found only on the mantle, rhinophores and at the base of the tubercles.

In the different body areas where these spicules are present, they are not arranged in the same way. For instance, in the mantle, the fusiform spicules form a network composed of a series of multispicular bundles that form a skeleton which is exclusively made up of agglutinated fusiform spicules, mostly arranged in the same direction. The crisscrossed arrangement of these bundles in the ventral mantle or subnotum delimits small spaces of different shapes, forming a triangular or polygonal reticulation (Figs. 4D, 6G). The spicules of the subnotum have a smaller size range, $86 \%$ of which are restricted to a range of 111-260 $\mu \mathrm{m}$ in length (Fig. 5C).

In transversal section of the mantle (Fig. 6C) the multispicular ascending tracts branch and intertwine more densely at the mantle margins (Fig. 4E). In the dorsal mantle or notum where the tubercles are located, the ascending multispicular bundles show larger gaps between them, as they converge at the base of the tubercles. The greater the number and size of the converging tracts are, the larger the tubercle (Figs. 6C,F). This originates a thick spicular stem of the tubercle (Fig. 4G), from the upper end of the stem, a broad bundle of spicules is arranged radially with their ends outwards but without crossing the epidermis, forming a hemispherical set (Figs. 4F, 6F). The mantle spherules are arranged in an apparently irregular shape and are distributed throughout the mantle up to the base of the tubercles where there are no spherules. The spicules of the notum have the largest size range between $70-770 \mu \mathrm{m}$ in length, of which $93 \%$ are restricted to a range of $111-470 \mu \mathrm{m}$ in length (Fig. 5B).

In the mantle tubercles there are only fusiform spicules that have a reduced size range, very similar to those of the foot, as $85 \%$ of the spicules are circumscribed to a range of 141-320 $\mu \mathrm{m}$ in length (Fig. 5D). In the foot there are only fusiform spicules which form a less complex but denser net than in the mantle (Fig. 4h, 6G), because the spicules do not form multispicular bundles but an irregular and complex net of abundant spicules. The spicules of the foot have a smaller size range than the dorsal mantle, $93 \%$ of which are restricted to a range of $110-350 \mu \mathrm{m}$ in length (Fig. 5F).

Both types of spicules are present in the rhinophores, the fusiform spicules are irregularly arranged parallel to the axis of the rhinophore stalk while in the lamellae they are less numerous but arranged horizontally radially (Fig. $4 \mathrm{C}, 6 \mathrm{E})$; the spherules in the rhinophore are only irregularly placed on the stalk, there are none in the lamellae. The rhinophore spicules show a different size distribution, as $99 \%$ of the spicules are distributed in a size range between 180-650 $\mu \mathrm{m}$ in length, with no more than 2 spicules outside this range (Fig. 5G).

Finally, only fusiform spicules are found on the branchial leaves and they are irregularly placed, from the base to the middle of the rachis, being less numerous than in the other parts of the animal. In the gills, the size range is small, as $94 \%$ of the spicules are confined to a size range between $111-350 \mu \mathrm{m}$ in length (Fig. 5E).

As can be seen in figure 6 (Figs. 6A-G) Doris adrianae sp. nov. presents a very complex skeletal structure, constituting a very characteristic armature in the different body areas. In the images of this figure only the skeletal structure is shown, as the organic matter has 

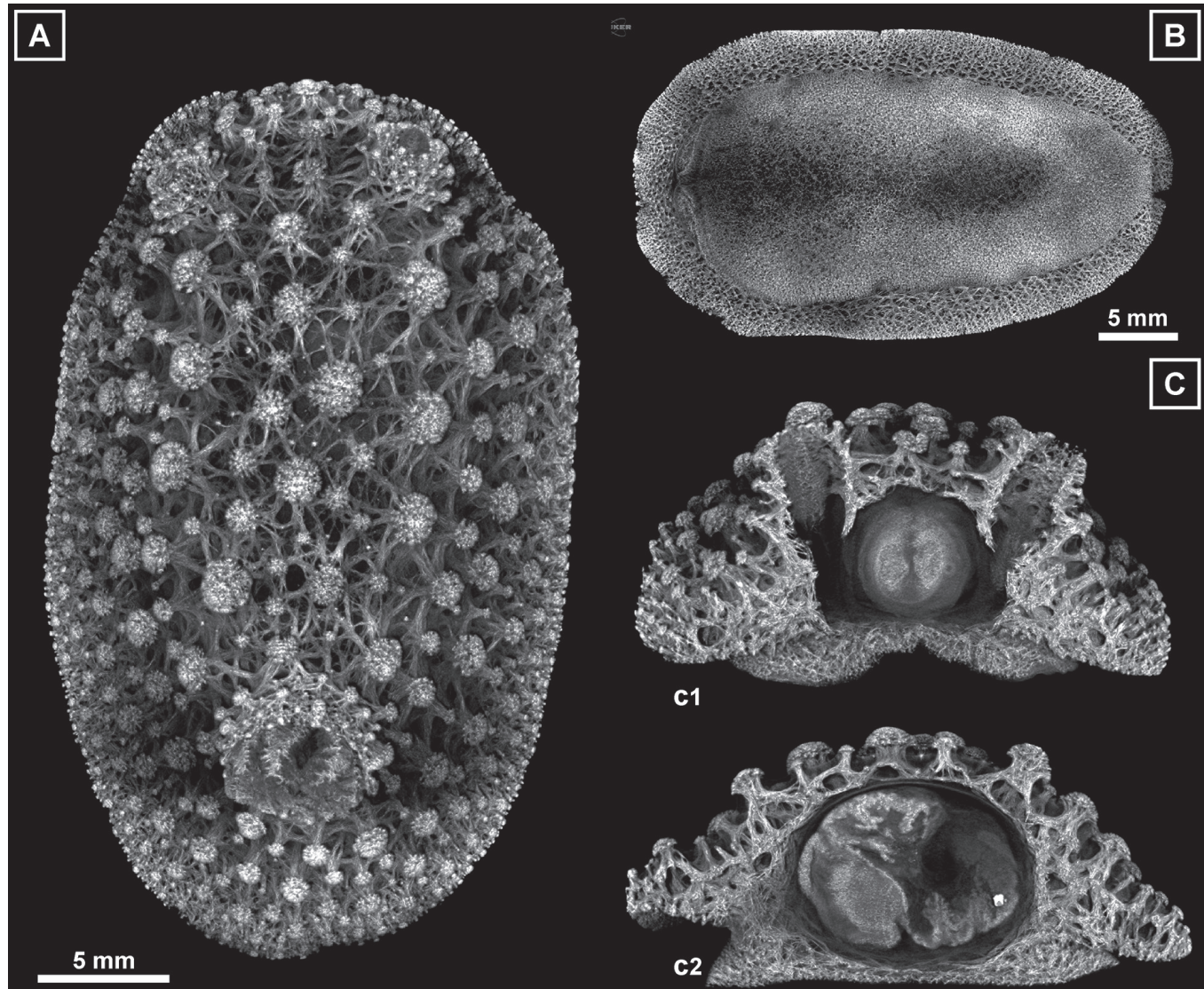

C1
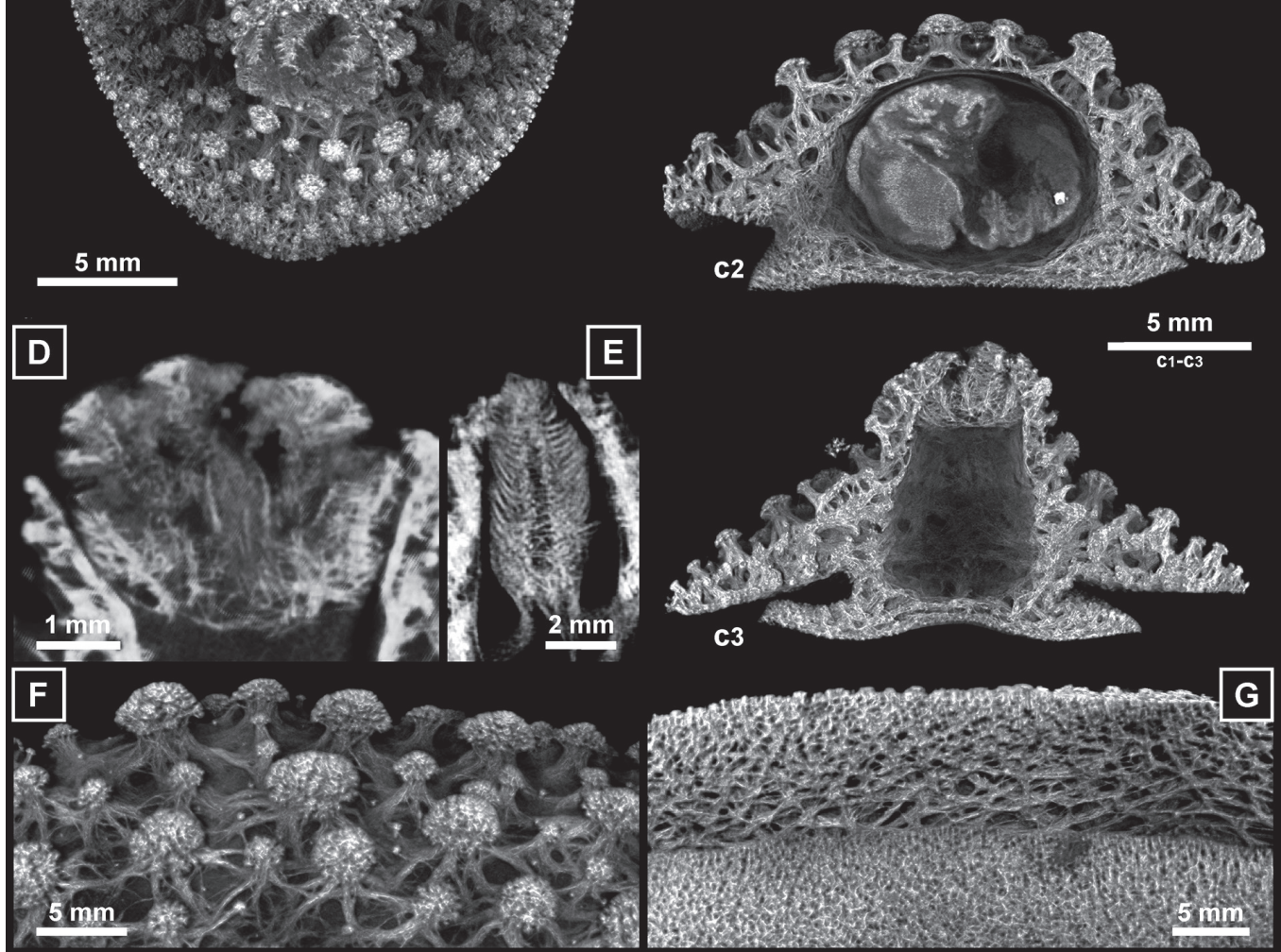

Figure 6. Doris adrianae sp. nov. Skeletal structure. A: Skeletal structure of the dorsal mantle and sheaths of the rhinophores and branchial leaves. B: Skeletal structure of ventral mantle and foot. C: Skeletal structure in cross-section: c1 at the level of the rhinophores, $\mathrm{c} 2$ at the level of the genital atrium and c3 at the level of the branchial leaves. D: Spicule density on branchial leaves. E: Density of spicules in the right rhinophore. F: Detail of the skeletal structure of the dorsal mantle. G: Detail of the skeletal structure of the ventral mantle and the edge of the foot. A-G: Paratype 1601240510,41 mm. (A-G Micro-CT).

Figura 6. Doris adrianae sp. nov. Estructura esquelética. A: Estructura esquelética del manto dorsal y vainas de rinóforos y branquias. B: Estructura esquelética del manto ventral y del pie. C: Estructura esquelética en sección transversal: c1 a nivel de los rinóforos, c2 a nivel de la atrio genital y c3 a nivel de las branquias. D: Densidad de espículas en las branquias. E: Densidad de espículas en el rinóforo derecho. F: Detalle de la estructura esquelética del manto dorsal. G: Detalle de la estructura esquelética del manto ventral y del borde del pie. A-G: Paratipo 16 01240510, 41 mm. (A-G Micro-CT). 
been removed, except in the visceral cavity. Despite this complex structure, it neither limits nor hinders the animal's ability to move, its body shape or adaptation to the substrate surface (Figs. 2A-G).

Digestive system: The digestive system occupies a large part of the visceral cavity (Figs. 9A-D) and begins in a mouth flanked by two oral lobes (Figs. 3I,K). The oral mass is composed of a rounded buccal bulb and a shorter glandular oral tube. The posterior part of the oral tube has six strong retractor muscles (Fig. 7K), three on each side, which attach to the body wall at the posterior part of the buccal bulb. The intermediate pair of muscles bifurcates almost at the beginning into two divergent muscles (mot 2 in Fig. $7 \mathrm{~K}$ ). The buccal bulb is rounded in shape, almost twice as large as the oral tube, with a radular sac emerging from the posterior ventral surface and recurved posteriorly (Fig. 7K). From the posterior-lower half of the buccal bulb arise a pair of long, strong retractor muscles, one on each side, which insert into the body wall, roughly towards the middle of the visceral cavity where the hermaphrodite and digestive glands begin (Fig. 7K).

At the anterior end of the pharynx, towards the oral tube, there is a chitinous labial cuticle of pelted shape, the labial disc (Fig. 7G), whose frontal surface is smoothly roughened, while the surface of the central canal is much rougher (Fig. 7G). In the posterior part of the pharynx, the oesophagus opens at the upper end (Figs. 7I,K). Two long salivary glands connect with the pharynx on either side of the oesophageal junction, between the visceral loop and the oesophagus, on either side of the buccal ganglia (Figs. 7H-K); they are ribbon-shaped, wider in their initial section, and extend ventrally, running under the visceral mass to the mid-height of the stomach.

It has a multidenticulate radula (Fig. 7B), whose radular formula is $38-50 \times 3-4 ; 33$ $53 ; 0 ; 33-53 ; 3-4$. The radula lacks a rachidial tooth The lateral teeth are of simple hooked shape, with a strong ridge more marked the larger the tooth, the tip of the tooth is slightly blunt and its surface is smooth (Figs.
7A,C). The first central lateral teeth are more curved, being more hooked than the others (Figs. 7D,E). The marginal teeth are similar to the lateral ones but the hooked edge is not smooth but feathery, the first ones having a slightly hooked shape, while the outermost ones acquire a feathery spade-like appearance (Fig. 7F).

The oesophagus is long and curved and opens laterally to the stomach which is large, curved and of variable diameter, opening posteriorly to the digestive gland. There is a gastric caecum that opens into the stomach very close to where it connects to the oesophagus and digestive gland. From the left anterior part of the stomach a long intestine emerges dorsally, it crosses across the visceral mass dorsally and runs along the right side of the animal, until it enters laterally into the gill crown, in the centre of which the anus is located (Figs. 7I, 9C,D). The digestive gland is interspersed with the hermaphrodite gland, although most of the gonad surrounds the digestive gland superficially (Fig. 8G).

Nervous system: In the central nervous system (Fig. 8A) the cerebral and pleural ganglia are fused and distinct from the pedal ganglia. There are four cerebral nerves emerging from each cerebral ganglion and three pleural nerves emerging from each pleural ganglion. From each of the pedal ganglia there are 5 pedal nerves. The rhinophore nerves emerge one from each cerebral ganglion, from a position more centred in the ganglion. The buccal ganglia (Figs. 7H, 8A) are located posterior to the buccal bulb, below the beginning of the oesophagus and are connected to the cerebral ganglia by two narrow, relatively short nerves. Very close to the buccal ganglia are the gastro-oesophageal ganglia. The optic ganglion is close to the insertion of the rhinophore nerve. The pedal and the parapedal commissures are together in the visceral loop.

Circulatory system: The circulatory system consists of a heart situated in the posterior part of the animal. The pericardial cavity is more or less circular, anterior to the branchial leaves ring and dorsal to the hermaphrodite and digestive glands. The auricle is funnel-shaped 


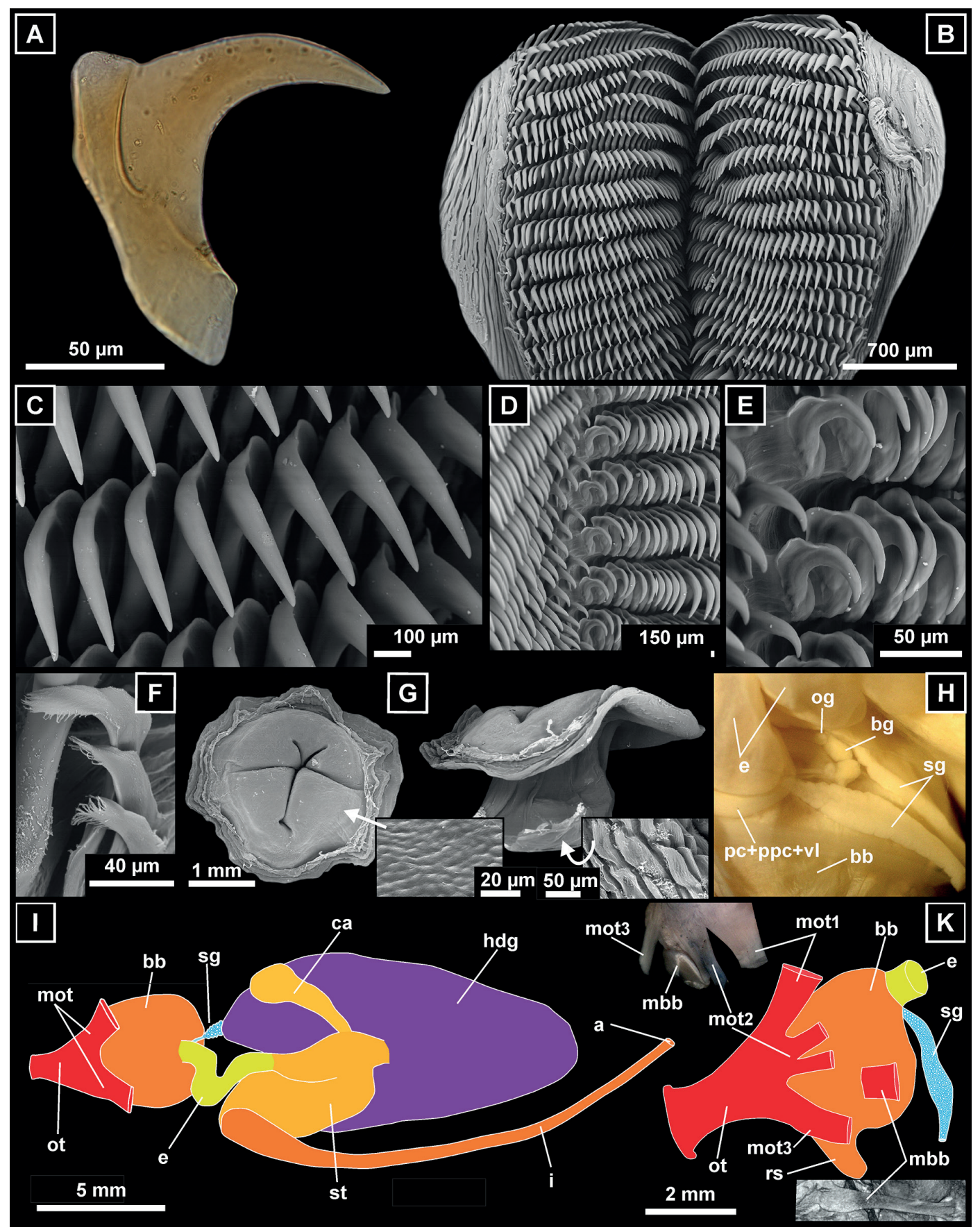

Figure 7. Doris adrianae sp. nov. Digestive system, radula and labial cuticle. A: Radula tooth, Paratype 10, 01080598-02, $45 \mathrm{~mm}$. B-C: Complete radula and detail of the mid-lateral teeth of the radula, Paratype 17, 01220807-01, 71 mm. D-E: Inner lateral teeth hooked, Paratype 7, 05030597, 60 mm. F: Outer marginal teeth plumose, Paratype 17, 01220807, 71 mm. G: Labial cuticle, Paratype 1, 01060786-01, 50 mm. H: Salivary glands, buccal ganglia and gastro-oesophageal ganglia, Paratype 7, 05130597-01, $60 \mathrm{~mm}$. I: Schematic drawing of the regionalization of the digestive system. K: Schematic drawing of oral tube and buccal bulb. (A,H LM. B-G SEM).

Figura 7. Doris adrianae sp. nov. Aparato digestivo, rádula y cutícula labial. A: Diente de la rádula, Paratipo 10, 0108059802, 45 mm. B-C: Rádula completa y detalle de los dientes laterales medios de la rádula, Paratipo 17, 01220807-01, 71 mm. D-E: Dientes laterales internos ganchudos, Paratipo 7, 05030597, 60 mm. F: Dientes marginales externos plumosos, Paratipo 17, 01220807, 71 mm. G: Cutícula labial, Paratipo 1, 01060786-01, 50 mm. H: Glándulas salivales, ganglios bucales y ganglios gastroesofágicos, Paratipo 7, 05130597-01, $60 \mathrm{~mm}$. I: Dibujo esquemático de la regionalización del aparato digestivo. K: Dibujo esquemático del tubo oral y del bulbo bucal. (A,H OM. B-G SEM). 

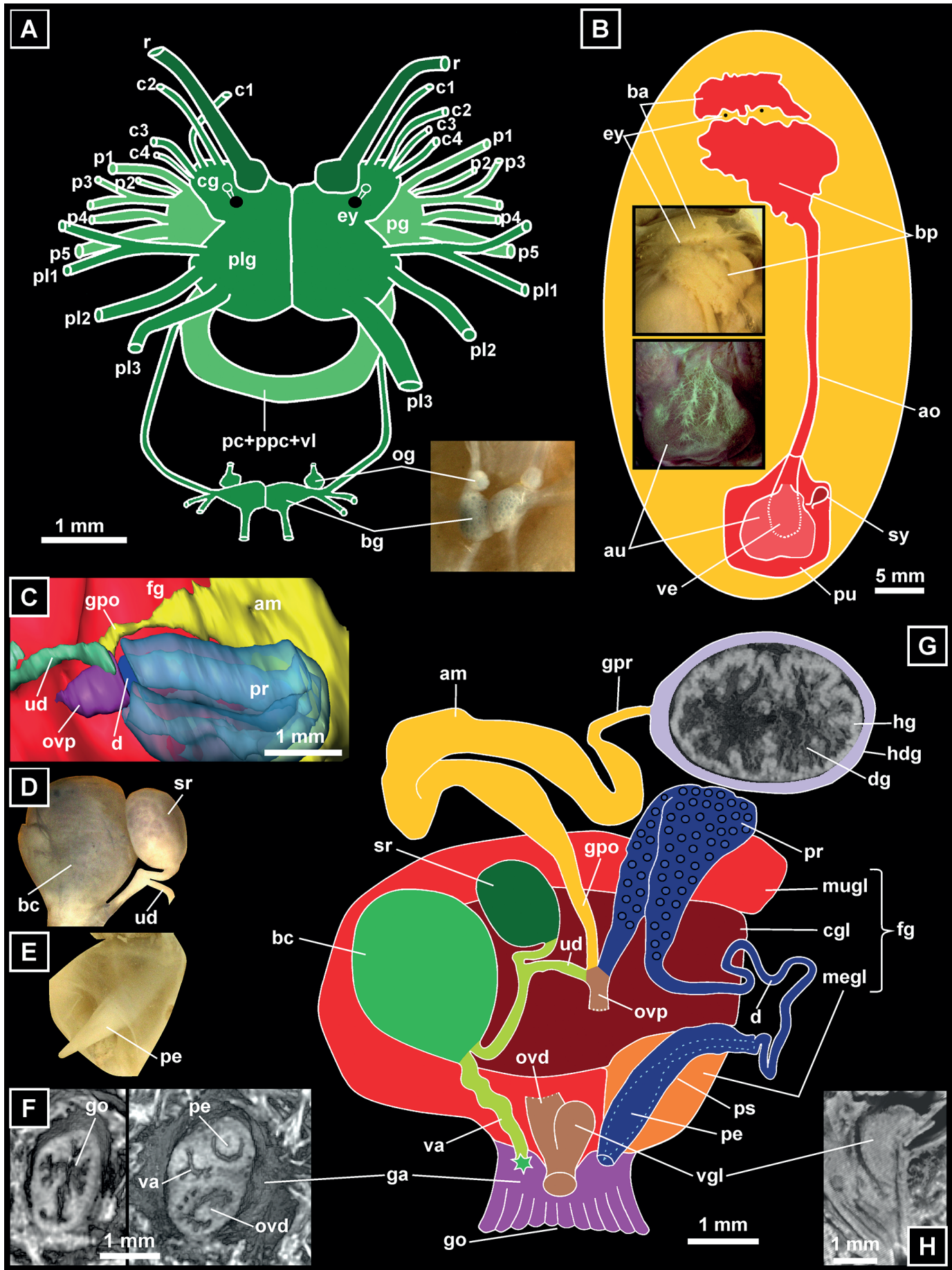

Figure 8. Doris adrianae sp. nov. Internal anatomy. A: Central nervous system, Paratype 7, 05130597-01, 60 mm. B: Circulatory system, Paratype 7, 05130597-01, $60 \mathrm{~mm}$. C: Confluent ducts in the distal oviduct. D: Bursa copulatrix and seminal receptacle, Paratype 7, 05130597-01, 60 mm. E: Penis, Paratype 17, 01220807-01, 71 mm. F: Openings in the genital atrium, Paratype 16 01240510, $41 \mathrm{~mm}$. G: Schematic drawing of the regionalization of the reproductive system. H: Vestibular gland, Paratype 16 01240510, 41 mm. (A,B,D,E LM. C 3D reconstruction with AVIZO 6.4. F,H Micro-CT). Figura 8. Doris adrianae sp. nov. Anatomía interna. A: Sistema nervioso central, Paratipo 7, 05130597-01, 60 mm. B: Aparato circulatorio, Paratipo 7, 05130597-01, $60 \mathrm{~mm}$. C: Conductos confluentes en el oviducto distal. D: Bursa copulatriz y receptáculo seminal, Paratipo 7, 05130597-01, 60 mm. E: Pene, Paratipo 17, 01220807-01, 71 mm. F: Aberturas en el atrio genital, Paratipo 16 01240510, $41 \mathrm{~mm}$. G: Dibujo esquemático de la regionalización del aparato reproductor. H: Glándula vestibular, Paratipo 16 01240510, 41 mm. (A,B,D,E OM. C Reconstrucción 3D con AVIZO 6.4. F,H Micro-CT). 
and provided with numerous small vessels (Fig. 8B); ventricle below the auricle, elongated in shape. In a $32 \mathrm{~mm}$ specimen, 68 beats per minute were counted in the heart. From the heart, a dorsal vessel runs through the animal towards the anterior region, where a large blood gland is located above the central nervous system; the blood gland consists of two parts, an anterior and a posterior part, which is the largest (Fig. 8B), revealing the eyes between them. The renal syrinx is elliptical and located on the right dorsal side of the pericardium, near the base of the auricle (Fig. 8B).

Reproductive system: The reproductive system is triaulic and is located in a right latero-dorsal position between the buccal bulb and the hermaphrodite and digestive glands (Fig. 9B). The genital opening is located in the subnotum (Fig. 3J), close to the epipodium, in the anterior third of the animal's length, through which the genital atrium is accessed, into which the penis, vagina and distal oviduct open (Fig. 8F). The hermaphrodite gland is interspersed with the digestive gland which it wraps superficially (Fig. 8G). The preampullar gonoduct is short and narrow and joins the ampulla above the stomach and below the intestine. The ampulla is long, tubular and thick, and folds in on itself before narrowing into the postampullar gonoduct which is short and narrow connecting with the proximal oviduct (Figs. 8C,G, 9E,F,G). The penis is small, elongated, fusiform and unarmed (Fig. 8E), covered by a muscular penial sheath which has some fusiform spicules in its distal part. A narrow, long and sinuous deferent duct, emerges from the penis and opens into a large, tubular, granular prostate that folds back on itself, finally connecting through a short deferent duct to the proximal oviduct (Figs. 8C,G, 9 E,F,G).

The vagina is short and wide and the proximal end of the vaginal duct joins the bursa copulatrix. From the bursa copulatrix another duct leads to the uterine duct and the seminal receptacle (Figs. 8C,D, G, 9E,F,G). The bursa copulatrix is large, globose and oval in shape, about three times larger than the seminal receptacle which is also globose and oval. Both have smooth surfaces with slight bulges (Fig. $8 \mathrm{D})$. The short uterine duct together with the deferent duct and the postampullary gonoduct open into the proximal oviduct which after a short section penetrates the female gland through the capsule gland (Fig. 8G).

The capsule gland is centrally located and of medium size; the membrane gland, the smallest, is located in the ventral anterior area; the mucus gland, the largest, surrounds the others except in the anterior region (Fig. $8 \mathrm{G})$. In the final section of the distal oviduct, near its opening in the genital atrium, there is a globular structure of glandular appearance which could be a vestibular gland, most likely as an adhesive region (Figs. 8G,H, 9H).

DNA sequence data and phylogenetic analysis: The cox 1-5' sequence for Paratype 20, DNA is available under GenBank accession number MW602531. The genetic distance between Doris adrianae sp. nov. and other Doris species was large (mean proportion of identical sites $=$ $80.9 \% \pm 1.5$ (S.D.)) although similar to the ones among Doris sequences available in GenBank (see Table 1). The bayesian phylogenetic tree shows Doris adrianae sp. nov. as sister species of a clade with Doris wellingtonensis, Doris montereyensis, Doris pseudoargus and Doris nobilis, with a relatively high support for the node $($ Bayesian posterior probability $=0.709$, Fig. 10).

Spawning: The spawning is hyaline white, slightly greyish and with the upper edge of the band brown, while the lower edge is hyaline. The spawning is in the form of a festoon ribbon with 2 to 2.5 turns and 26 to 31 waves (Fig. 9K). The height of the ribbon is $15 \mathrm{~mm}$. The egg capsules have a linear arrangement from the upper to the lower edge, but oblique or arched across the width of the ribbon, although this tendency is more evident towards the upper edge and less noticeable in the lower half (Fig. 9I). The capsules have 1, 2, 3 or 4 eggs, but mostly two (Fig. 9I). On the upper edge of the ribbon the egg capsules are arranged almost close to the margin, while on the lower edge there is a small hyaline strip devoid of eggs which is the line of attachment 

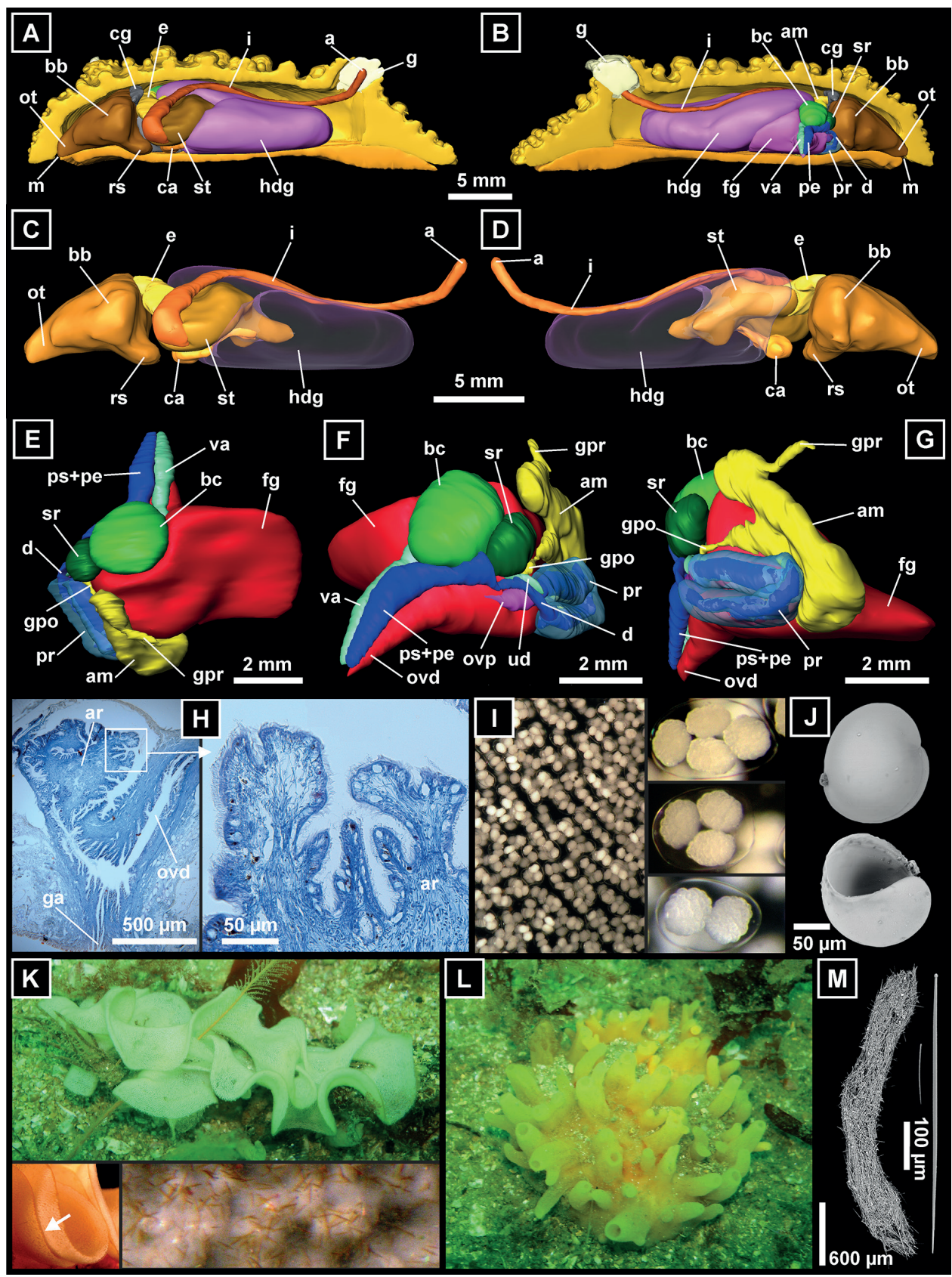

Figure 9. Doris adrianae sp. nov. 3D reconstruction of internal anatomy, adhesive region, feeding and spawning. A-B: Organs in situ, left (A) and right (B) sides. C-D: Digestive system in lateral view, left (C) and right (D). E-G: Reproductive system in dorsal (E), right anterior-lateral (F) and right posterior-lateral views (G). H: Adhesive region. I: Arrangement of eggs in the spawn and egg capsules in vivo. J: Larval shell (protoconch type I). K: Spawning in type locality (Castelo de San Felipe), brown upper edge (arrow) and fusiform spicules of the brown edge. L: The sponge Polymastia boletiformis (Lamarck, 1815) in type locality (Punta Fornelos). M: Faecal pellet full of spicules of P. boletiformis and small (133 $\mu \mathrm{m})$ and large $(586 \mu \mathrm{m})$ tylostyles of the faecal pellet. (A-G 3D reconstruction with AVIZO 6.4. H LM. J,M SEM. I,K,L in vivo). Figura 9. Doris adrianae sp. nov. Reconstrucción en 3D de la anatomía interna, región adhesiva, alimentación y desove. A-B: Órganos in situ, lateral izquierdo (A) y derecho (A). C-D: Aparato digestivo en vista lateral, izquierda (C) y derecha (D). E-G: Aparato reproductor en vista dorsal (E), antero-lateral derecha (F) y postero-lateral derecha (G). H: Región adhesiva. I: Disposición de los huevos en la puesta y cápsulas con huevos in vivo. J: Concha larvaria (protoconcha tipo I). K: Puesta en la localidad tipo (Castelo de San Felipe), borde superior marrón (flecha) y espículas fusiformes del borde marrón. L: La esponja Polymastia boletiformis (Lamarck, 1815) en la localidad tipo (Punta Fornelos). M: Pelota fecal repleta de espículas de $P$. boletiformis y tilostilos pequeños $(133 \mu \mathrm{m})$ y grandes $(586 \mu \mathrm{m})$ de las pelotas fecales. (A-G Reconstrucción 3D con AVIZO 6.4. H OM. J,M SEM. I,K,L in vivo). 


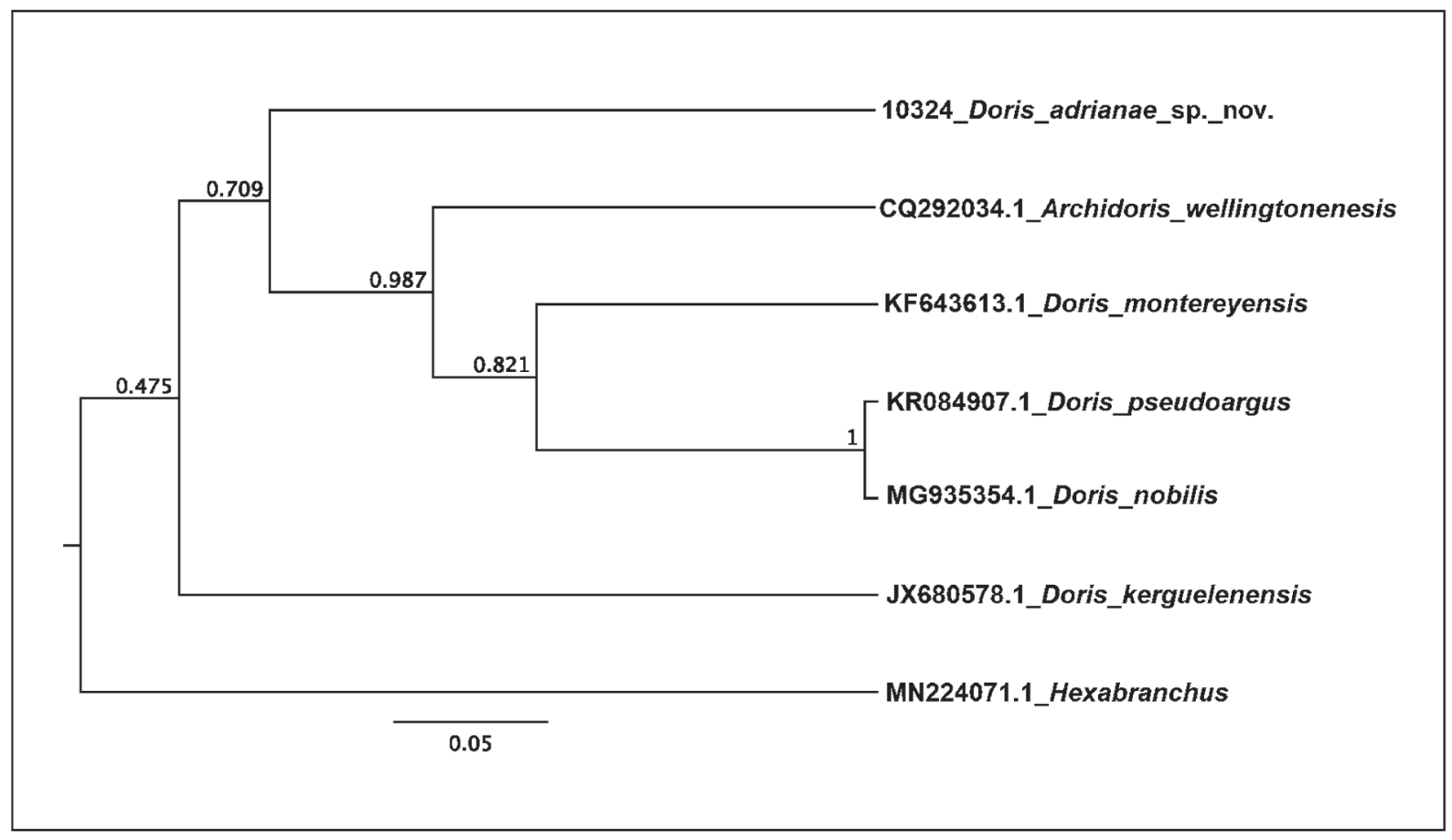

Figure 10. Doris adrianae sp. nov. Phylogenetic tree resulting from BEAST analysis of Doris adrianae sp. nov. and cox1-5' sequences of Doris sequences downloaded from GenBank One GenBank sequence has been selected for each species. Node values represent Bayesian posterior probabilities.

Figura 10. Doris adrianae sp. nov. Árbol filogenético resultante del análisis BEAST de Doris adrianae sp. nov. y de las secuencias cox 1-5' de Doris descargadas de GenBank Se ha seleccionado una secuencia de GenBank para cada especie. Los valores de los nodos representan las probabilidades posteriores bayesianas.

to the substratum. A preparation under light microscopic of the upper edge of the ribbon revealed that the brown colour of the edge was due to the presence of fusiform spicules like those found in adult specimens on the mantle and foot (Fig. 9K). The larval shell is a smooth type I protoconch (THOMPSON, 1961) with a large turn of the spire and a wide oval opening with a smooth edge (Fig. 9J).

Habitat and associated fauna: The three localities of the Ría de Ferrol where the specimens were collected between 11 and 20 $\mathrm{m}$ deep, have a very similar habitat, characterised by the existence of extensive, flat and low rocky outcrops of granodiorites, where a forest of the gorgonian Leptogorgia lusitanica (Stiasny, 1937) is located. By its proximity to a sandy-muddy sedimentary bottom, the rock surface is covered with a thin layer of fine sediment. The community beneath the gorgonian forest is devoid of large algae, but shows a wide diversity of sessile invertebrate species where certain species of sponges
Polymastia boletiformis (Lamarck, 1815), Mycale (Aegogropila) antiae Urgorri \& DíazAgras, 2019, Cliona celata Grant, 1826, Adreus fascicularis (Bowerbank, 1866), Desmacidon fruticosum (Montagu, 1814), Ciocalypta penicillus Bowerbank, 1862 and Haliclona (Haliclona) oculata (Linnaeus, 1759), the cnidarians Dynamena pumila (Linnaeus, 1758), Sertularella gayi (Lamouroux, 1821), Aglaophenia acacia Allman, 1883, Actinothoe sphyrodeta (Gosse, 1858), Epizoanthus arenaceus (Delle Chiaje, 1823), Caryophyllia smithii Stokes \& Broderip, 1828, Eunicella verrucosa (Pallas, 1766) and Alcyonium digitatum Linnaeus, 1758 , the bivalve Mimachlamys varia (Linnaeus, 1758), the polychaete Sabellaria alcocki Gravier, 1906 and the ascidian Stolonica socialis Hartmeyer, 1903 and also other species of vagile invertebrates, such as the molluscs Calliostoma zizyphinum (Linnaeus, 1758), Turritella communis Risso, 1826, Tritia reticulata (Linnaeus, 1758), Trapania tartanella (Ihering, 1886 in Ihering, 1886b) and Cadlina 
laevis (Linnaeus, 1767) and the echinoderms Marthasterias glacialis (Linnaeus, 1758), Echinus esculentus Linnaeus, 1758 and Holothuria forskali Delle Chiaje, 1823.

Feeding behaviour: The study of the contents of the faecal pellets obtained from live animals of Doris adrianae sp. nov. (Fig. 9M), as well as the digestive contents of the 4 dissected animals and that of the serial sections of two specimens (paratypes 4 and 15), revealed a spicular composition of tylostyles, identical to that of the sponge Polymastia boletiformis (Lamarck, 1815). This sponge has two types of tylostyles, some large $(500-700 \mu \mathrm{m})$ fusiform, rectilinear, with a tylo at one end and the other ending in a point, and others small (125-190 $\mu \mathrm{m})$ fusiform, slightly curved and with a scarcely marked tylo (Fig. 9M). The exclusive presence of Polymastia boletiformis (Lamarck, 1815) spicules in all the samples studied, without having found any other type of spicule, makes it possible to ensure that Doris adrianae sp. nov. feeds exclusively on the sponge Polymastia boletiformis (Lamarck, 1815), which is very abundant in the three type localities of the Ría de Ferrol (Fig. 9L) and that both species coincide remarkably in their colouring.

\section{DISCUSSION}

According to the diagnosis of the genus Doris Linnaeus, 1758 established by VALDÉs (2002), Doris adrianae sp. nov. clearly fits within the genus Doris on the basis of the absence of a notch on the anterior margin of the foot, the labial cuticle lacking rodlets, a radula composed of simple, hamate teeth, a penis and vagina devoid of hooks and also on the fact that it matches the other diagnostic characters of the genus (VALDÉs, 2002).

Furthermore, according to some diagnostic characters of the other genera that comprise the family Dorididae Rafinesque, 1815, it could not be classified in any of them, as there are clear differences with Doris adrianae sp. nov. For example, the genus Aphelodoris Bergh, 1879 differs in that it does not have integumentary spicules and has a smooth dorsum without tubercles (VALDÉs, 2002).
Doris adrianae sp. nov. could not be classified within the genus Conualevia Collier \& Farmer, 1964 because this genus has mantle glands and rhinophores almost smooth, with several irregular and inconspicuous lamellae (VAldés, 2002). The genus Goslineria Valdés, 2001 has several large sacs sacs in the genital atrium, each containing a long, simple, flexible spine (VALDÉs, 2001), which are absent in $D$. adrianae sp. nov. It also does not belong in the genus Artachaea Bergh, 1881 in BERGH, 1881b, because Artachaea has oral tentacles and the penis is armed with spines (VALDÉs, 2002), which Doris adrianae sp. nov. lacks (VALDÉs, 2002). The genus Pharadoris Valdés, 2001, has a genital atrium with two large glands, each containing a long, bifid, rigid spine, which Doris adrianae sp. nov. does not have. The genus Doriopsis Pease, 1860 is characterised by a wide semicircular crown of gill leaves very different from those of Doris adrianae sp. nov.

Undoubtedly, the most reliable diagnostic character of Doris adrianae sp. nov. that clearly differentiates it from the rest of the species of the genus Doris, is the skeletal structure that forms a dense net of spicules, in a complex network of multispicular bundles.

Dorids are known to have tegumentary spicules, although most papers describe their presence as spicules radiating from the base of the tubercles and other vertical spicules supporting the tubercles (KRESS, 1981; Cattaneo-Vietti, et al. 1993; Brodie, 2004; Ehrlich, 2019; Ortea \& Espinosa, 2017; among others). Some authors make more detailed descriptions of the skeletal structure of dorids (García, et al. 1986; Penney, 2006), in some use micro-computed tomography (ALBATercedor \& Sanchez-Tocino, 2011; Penney, et al. 2018; Penney, et al. 2020) and include species of the genus Doris (Penney, 2008) such as Doris montereyensis Cooper, 1863, but none of these studies describe a skeletal structure as complex as that of Doris adrianae sp. nov. This complex skeletal structure could initially be interpreted as having a primarily defensive or at least deterrent function for potential predators (Thompson, 1960; Ros, 1976), but, probably in $D$. adrianae sp. nov. they also 
have a structural function, a function that was described by CATTANEO-VIETTI, et al. (1993) in Peltodoris atromaculata Bergh, 1880, stating that they have an important role in determining the firmness, structure and architecture of the notum.

Of the genus Doris Linnaeus, 1758, 51 species are currently recognised as valid (WoRMS, 2021), generally with an external appearance different from that of Doris adrianae sp. nov. Of these, 13 are distributed along the Northeastern Atlantic which ranges from Sweden to Cape Verde. All these species, in addition to differing in skeletal structure, they exhibit other characters different from Doris adrianae sp. nov. For example, Doris atypica (Eliot, 1906), Doris bicolor (Bergh, 1884 in BERGH, 1884a), Doris ocelligera (Bergh, 1881 in BERGH, 1881a) and Doris verrucosa Linnaeus, 1758, have unipinnate branchial leaves and Doris marmorata Risso, 1818 and Doris pseudoverrucosa (Ihering, 1886 in IHERING, 1886a) show bipinnate branching and in addition these six species have rhinophoral sheaths with two lateral tubercles that close the rhinophoral cavity like two valves (Eliot, 1906; Ortea \& Moro, 2017; Bergh, 1884a; Pruvot-Fol, 1954; Ortea, et al. 2014; Cattaneo-Vietti, et al. 1990; VAldÉs, 2002; Lima \& Simone, 2015; IHERING, 1886a; SCHMEKEL, 1968; SCHMEKEL \& Portmann, 1982). Doris hayeki Ortea, 1998 and Doris morenoi Ortea, 1989 also have unipinnate leaves, both exhibit hooked marginal teeth without denticles and their bursa copulatrix is slightly larger (x1.5) than the seminal receptacle (ORTEA, 1989, 1998). The remaining five species have tripinnate or bipinnate leaves, but Doris nobilis Odhner, 1907, Doris sticta (Iredale \& O'Donoghue, 1923) and Doris bertheloti (d'Orbigny, 1839) have rhinophoral sheaths with two lateral tubercles and the marginal teeth are hooked without denticles (OdHner, 1907, 1926; ThOMPSON \& Brown, 1984; Hunnam \& Brown, 1975; Gavaia, et al. 2003; D'Orbigny, 1839; Ortea \& Bacallado, 1981; Perrone, 1989), while Doris alboranica Bouchet, 1977 also has hooked marginal teeth without denticles and a bursa copulatrix globose and much larger than the seminal receptacle which is pyriform (Bouchet, 1977). In Doris pseudoargus Rapp, 1827 the bursa copulatrix is irregular in shape, about 10 times larger than the seminal receptacle and shows a single large blood gland (VALDÉs, 2002). All of the above characters clearly differentiate these thirteen eastern North Atlantic species from Doris adrianae sp. nov., which corroborates the validity of this new species.

In general, the internal anatomy of $\mathrm{Do}$ ris adrianae sp. nov. matches the diagnostic characters of the genus Doris established by VALDÉS (2002). However, in the description of the reproductive apparatus (vide supra) it is explained that in the final section of the distal oviduct, close to its opening in the genital atrium, there is a globular structure of glandular appearance that could be a vestibular gland, most likely as an adhesive region (Figs. 8G,H, 9H). This is the only character that does not coincide with the diagnosis of the genus Doris, in which VALDÉs (2002) states that vestibular or accessory glands absent. It is not a vestibular gland in its usual sense, which is very diverse, as it is usually described, sometimes as a clearly visible and prominent pouch, and sometimes as a small swelling, of diverse location in the genital opening, in the opening of the oviduct, on one side or at the end of the female glandular mass and with lobulated, branched, blind tubule-like forms, among others. This type of vestibular gland was widely mentioned in species of several families of the Infraorder Doridoidei, but it is considered that these glands are not homologous among these families (RUdMAN, 1985, 1987; Gosliner, 1994; JoHnson \& Gosliner, 1998; VALDÉs \& CAMPILlO, 2000; VALDÉs, 2002).

WÄGELE $(1985 ; 1989)$ described a specialised glandular tissue near the distal oviduct opening in Phyllidia pulitzeri Pruvot-Fol, 1962 and Austrodoris kerguelenensis (Bergh, 1884 in BERGH 1884b) which she refers to as the adhesive region or "Kleberegion", a term already used by SCHMEKeL (1971). WÄGELE, et al. (1999) consider in Dendrodoris nigra that the function of the vestibular gland has more to do with egg laying than receipt of sperm and Klussmann-Kolb \& Brodie (1999) who studied it histologically and ultrastructurally, observed that internally the gland itself presents 
a characteristic convoluted appearance and that the position of the gland seems to reflect a specific function in the final stages of egg mass production.

Klussmann-Kolb (1999; 2001a; 2001b) did histological and ultrastructural research on the nidamental glandular system in several heterobranchs sea slugs (Cephalaspidea, Aplysiida, Sacoglossa and Nudibranchia), describing in detail a specialised glandular epithelium lining the most distal part of the oviduct, consisting of columnar glandular cells with short to moderately long cilia, which he named adhesive region. The vestibular gland located in the distal oviduct of the genital tract of Doris adrianae sp. nov. with ciliated columnar cells (Fig. 9H) has remarkable similarities with the adhesive region described by Klussmann-Kolb (2001b). Thus, considering that the adhesive region is frequent in several dorid species, because it is the part where the secretion of an adhesive substance that binds the eggmasses to the substratum takes place, it must also be present in many other dorid species (WÄGELE, personal communication). However, a detailed histological and ultrastructural study of the nidamental gland of Doris adrianae sp. nov. will be necessary to determine with certainty that it is undoubtedly an adhesive region.

As explained, the egg mass of Doris adrianae sp. nov. is a festoon ribbon of 2 to 2.5 turns with one edge adhering to the substratum and with the upper edge brown due to the presence of fusiform spicules. In the scientific literature on nudibranchs (FERNANDEZ-OVIES \& Ortea, 1981; KlussmanN-Kolb \& WäGele, 2001; Wilson, 2002; among others) no reference was found describing in any species the presence of spicules on the egg ribbon, which reveals another very specific character in Doris adrianae sp. nov.

As far as feeding is concerned, it is a known fact that poriferans are the basis of the diet of dorids. Apparently, the diet does not seem to be very selective, because in many occasions the sponges on which the animals are placed are considered as food. This fact should not be taken for granted, the most reliable way is to analyse the spicules of the faecal pellets, which even allows us to obtain proportions in the case that the dorid feeds on more than one species of sponge. Thus, URGORRI \& Besteiro (1984) by faecal pellet analysis obtained a proportion of spicules of $70 \%$ of Hymeniacidon perlevis (Montagu, 1814) and $30 \%$ of Halichondria panicea (Pallas, 1766) in Doris verrucosa. In Doris pseudoargus $80 \%$ of the spicules of Hymeniacidon perlevis (Montagu, 1814) and $20 \%$ of Halichondria panicea (Pallas, 1766) were obtained in one occasion and $100 \%$ of Halichondria panicea (Pallas, 1766) in another occasion.

Consequently, dorids do not feed on the species that are available in their environment, but rather they are located in those habitats where the species they prey on are present. To verify this fact, all the sponge species of large size present in the type locality were collected and identified (vide supra Habitat and associated fauna), in order to check the availability of potential food, including Polymastia boletiformis (Lamarck, 1815). Additionally, the faecal pellets of the holotype and 11 paratypes (4, $6,8,9,13,17,18,18,19,20,21$ and 22), the digestive contents of the dissected paratypes $(1,7,10,12$ and 17) and the histological sections of paratype 15 were analysed. In all of them the result was the same, they contained only the tylostyles of Polymastia boletiformis.

In conclusion, it can be stated that Doris adrianae sp. nov. feeds exclusively on Polymastia boletiformis despite the presence of six other sponge species of good size in the environment in which it lives. It is also deduced that Doris adrianae sp. nov. is only found in habitats where Polymastia boletiformis is present, due to a monospecific predator-prey relationship, not appearing in other infralittoral bottoms of the Ría de Ferrol where several species of porifera are very abundant but where Polymastia boletiformis is not present, which determines the habitat where Doris adrianae sp. nov. is found.

Finally, as explained in the material and methods (vide supra DNA analysis), a total of 177 cox 1-5' sequences with in the genera Doris, Archidoris and Austrodoris were downloaded 
from GenBank in December 2020, whose full list of downloaded sequences is provided in Supplementary material Appendix 1. Doris adrianae sp. nov. has a high genetic distance to other species of the genus Doris whose sequences are available in GenBank. However, this high genetic distance (approx. 20\% of different nucleotides in the barcode fragment) is similar to that among other Doris species (except for the species pair Doris nobilis and Doris pseudoargus). The Bayesian tree constructed with Beast (Fig. 10), shows Doris adrianae sp. nov. as a sister species to the clade composed of Doris wellingtonensis, Doris montereyensis, Doris pseudoargus and Doris nobilis, although the support for this relationship is not high $($ Bayesian posterior probability $=0.709)$. However, it should be noted that this phylogenetic analysis has been carried out on the basis of the sequences available in GenBank and, therefore, the diversity of the genus Doris, for which 51 species are recognised (WoRMS, 2021), is under-represented. Therefore, genetic distances could be smaller with other species that are not currently represented in GenBank.

\section{ACKNOWLEDGEMENTS}

The authors would like to thank Dr. Gonçalo Calado, Dr. Ramiro R. Tato, Dra. Xela Cunha and Dr. Marcos Abad for their collaboration in collecting the samples by SCUBA diving. We would like to thank Gonzalo Montoto for the data and photographs of the specimens from O Grelle (Ría da Coruña). We thank Prof. Dr. Heike Wägele for her bibliographical assistance and wise comments. We would also like to thank Raquel Antón and Ramiro Barreiro from the Electronic Microscopy Service of the USC, for their help in making the images at SEM. We are grateful for the support of the infrastructure PRISC - Portuguese Research Infrastructure for Scientific Collections through the Science Museum of the University of Coimbra. We thank Miquel Pontes (OPK) for his bibliographical assistance. In addition, we are very grateful to Julia García who kindly checked the English version of the paper. We are also grateful to three anonymous reviewers for their comments which have helped to improve this paper.

\section{REFERENCES}

Alba-Tercedor, J. \& Sánchez-Tocino, L. (2011). The use of the SkyScan 1172 high-resolution micro-CT to elucidate if the spicules of the sea slugs (Mollusca: Nudibranchia, Opisthobranchia) have a structural or a defensive function. SkyScan Users Meeting 2011: 113-121.

Allman, G.J. (1883). Report on the Hydroida dredged by H. M. S. Challenger during the years 1873-76. Part I Plumulariidae. The Voyage of H. M. S. Challenger, Zoology, 20: 1-55.

BAÑón, R. (Eds.). (2017). Inventario de la biodiversidad marina de Galicia: Proyecto LEM$G A L$. Consellería do Mar Dirección Xeral de Desenvolvemento Pesqueiro. Xunta de Galicia. 570 pp.

Bergh, L.S.R. (1879). Neue Chromodoriden. Malakozoologische blätter, Neue Folge, 1: 87-116.

Bergh, L.S.R. (1880). Malacologische Untersuchungen. In: Reisen im Archipel der Philippinen von Dr. Carl Gottfried Semper. Zweiter Theil. Wissenschaftliche Resultate. Band 2, Theil 4, Heft 1, pp 1-78.

BERGH, L.S.R.(1881a). Malacologische Untersuchungen. In: Reisen im Archipel der Philippinen von Dr. Carl Gottfried Semper. Zweiter Theil. Wissenschaftliche Resultate. Band 2, Theil4, Heft 2, pp 79-128.

BERGH, L.S.R. (1881b). Beiträge zur Kenntniss der japanischen Nudibranchien. II. Verhandlungen der Kaiserlich-Königlichen ZoologischBotanischen Gesellschaft in Wien, 31:219-254.

BERGH, L.S.R. (1884a). Malacologische Untersuchungen. In: Reisen im Archipel der Philippinen von Dr. Carl Gottfried Semper. Zweiter Theil. Wissenschaftliche Resultate. Band 2, Theil 3, Heft 15, pp 647-754.

BERGH, L.S.R. (1884b). Report on the Nudibranchiata collected by H.M.S Challenger during the years 1873-1876. Report on the Scientific Results of the Voyage of H.M.S. Challenger during the years 1873-76. Zoology. 10 (part 26): 1-154, pl. 1-14.

Blainville, H.M.D. de (1814). Mémoire sur la classification méthodique des animaux 
mollusques, et établissement d'une nouvelle considération pour y parvenir. Bulletin des Sciences par la Société Philomatique de Paris, Zoologie, 1814: 175-180. http://biodiversitylibrary.org/page/4121382

Bouchet, P. (1977). Opisthobranches de profondeur de l'océan atlantique: II. Notaspidea et Nudibranchiata. Journal of Molluscan Studies, 43(1):28-66. https://doi.org/10.1093/ oxfordjournals.mollus.a065359

Bouchet, P., Rocroi, J.P., Hausdorf, B., Kaim, A., Kano, Y., Nützel, A., Parkhaev, P., SchröDl, M.\& Strong, E.E. (2017). Revised classification, nomenclator and typification of gastropod and monoplacophoran families. Malacologia, 61(1-2): 1-526. https://doi. org/10.4002/040.061.0201

Bouchet, P. \& Valdés, A. (2000). Case 3088. Doris verrucosa Linnaeus, 1758 (Mollusca, Gastropoda): proposed conservation of the generic and specific names by designation of a neotype. Bulletin of Zoological Nomenclature, 57: 74-80.

Bouckaert, R., Vaughan, T.G., BaridoSottani, J., Duchêne, S., Fourment, M., GavryushkinA, A., et al. (2019). BEAST 2.5: An advanced software platform for Bayesian evolutionary analysis. PLoS computational biology, 15(4): e1006650. https:// doi.org/10.1371/journal.pcbi.1006650

Bowerbank, J.S. (1862). On the Anatomy and Physiology of the Spongiadae. Part III On the Generic Characters, the Specific Characters, and on the Method of Examination. Philosophical Transactions of the Royal Society, 152(2): 1087-1135. http://dx.doi.org/10.1098/ rstl.1862.0044

Bowerbank, J.S. (1866). A Monograph of the British Spongiadae. Vol. 2. Ray Society, London, 388 pp. http://dx.doi.org/10.5962/ bhl.title.56119

BRodIE, G.D. (2004). An unusual dendrodorid: redescription of the tropical nudibranch Dendrodoris atromaculata (Alder \& Hancock, 1864) (Anthobranchia: Doridoidea: Dendrodorididae). Zootaxa, 503: 1-13. https://doi. org/10.11646/zootaxa.503.1.1

Burmeister, H. (1837). Handbuch der Naturgeschichte, vol. 2, Zoologie. Enslin, Berlin. i-xii, pp. 369-858.
Candás, M., Díaz-Agras, G., Abad, M., Barrio, L., Cunha-Veira, X., Pedrouzo, L., Señarís, M.P., Tato, R., García-Álvarez, O. \& URGORRI, V. (2016). Application of microCT in the study of the anatomy of small marine molluscs. Microscopy and Analysis, 23, S8-S11.

Cattaneo-Vietti, R., Angelini, S. \& BavesTRELlo, G. (1993). Skin and gut spicules in Discodoris atromaculata (Bergh, 1880) (Mollusca: Nudibranchia). Bollettino Malacologico, 29(5-8): 173-180.

Cattaneo-Vietti, R., Chemello, R. \& GianNUZZI-SAVELli, R. (1990). Atlas of Mediterranean nudibranchs [ Atlante deinudibranchi del Mediterraneo ]. La Conchiglia. Roma, 264 pp.

Cervera, J.L., Calado, G., Gavaia, C., MalaQuias, M.A.E., Templado, J., Ballesteros, M., García-Gómez, J.C. \& Megina, C. (2004). An annotated and updated checklist of the opisthobranchs (Mollusca: Gastropoda) from Spain and Portugal (including islands and archipelagos). Boletín Instituto Español de Oceanografía, 20(1-4): 1-122.

Collier, C.L. \& FArmer, W.M. (1964). Additions to the nudibranch fauna of the East Pacific and the Gulf of California. Transactions of the San Diego Society of Natural History, 13: 377-396.

Cooper, J.G. (1863). Some new genera and species of California Mollusca. Proceedings of the California Academy of Natural Sciences, 2: 202-207.

Cuvier, G. (1795). Second Mémoire sur l'organisation et les rapports des animaux à sang blanc, dans lequel on traite de la structure des Mollusques et de leur division en ordre, lu à la société d'Histoire Naturelle de Paris, le 11 prairial an troisième [30 May 1795]. Magazin Encyclopédique, ou Journal des Sciences, des Lettres et des Arts, 2: 433-449.

Delle Chiaje, S. (1823). Memorie sulla storia e notomia degli animali senza vertebre del regno di Napoli. Vol. 1. Fratelli Fernandes, Napoli, 184 pp.

D'Orbigny,A.(1839). Mollusques, échinodermes, foraminifères et polypiers, recueillis aux Iles Canaries par MM. Webb et Berthelot et decrits par Alcide D'Orbigny. Mollusques - 1, 2(2): 1-117. 
Ehrlich, H. (2019). Spicules of Nudibranchia. In Marine Biological Materials of Invertebrate Origin; Biologically-Inspired Systems; Springer International Publishing. Springer: Cham, Switzerland, pp. 134-138.

Eliot, C.N.E. (1906). Report upon a collection of Nudibranchiata from the Cape Verde islands, with notes by C. Crossland. Proceedings of the Malacological Society of London, 7(3): 131-159.

Faulwetter, S., Vasileiadou, A., Kouratoras, M., Dailianis, T. \& Arvanitidis, C. (2013). Micro-computed tomography: introducing new dimensions to taxonomy. Zookeys, 263: 1-45. https://doi.org/10.5061/dryad.84m54

Fernandez-Ovies, C.L. \& Ortea, J.A. (1981). Contribucion a la clasificacion morfologica de las puestas de los Opisthobranquios (Mollusca: Gastropoda). Boletín de Ciencias de la Naturaleza I. D. E. A., 28: 3-12.

García, F.J., García, J.C. \& Cervera, J.L. (1986). Estudio morfológico de las espículas de Doriopsilla areolata (Gastropoda: Nudibranchia). Malacologia, 27(1): 83-96.

Gavaia, C., Malaquias, M.A.E., Calado, G. \& Urgorri, V. (2003). New records of Portuguese opisthobranch molluscs. Journal of Conchology, 38(2): 101-118.

Gil-Mansilla, E., García-Álvarez, O. \& Urgorri, V. (2008). Metodología para la recolección, conservación y el estudio de los Moluscos Solenogastros. Reseñas malacologicas, 12: 1-31.

Gofas, S. (2011). La distribución geográfica de los moluscos. pp. 23-30. In: Gofas S, Moreno D, Salas C (coords). Moluscos marinos de Andalucía. Málaga: Servicio de Publicaciones e Intercambio Científico, Universidad de Málaga. pp. 1-798.

Gofas, S., Luque, Á.A., Templado, J \& Salas, C. (2017). A national checklist of marine Mollusca in Spanish waters. Scientia Marina, 81(2): 241-254. https://doi.org/10.3989/ scimar.04543.21A

Gosliner, T.M. (1994). Gastropoda: Opisthobranchia. In: Harrison FW, Kohn AJ (eds) Microscopic anatomy of invertebrates. Vol. 5. Mollusca I. Wiley-Liss, Inc., New York, pp. 253-355.
Gosse, P.H. (1858-1860). Actinologia Brittanica: a history of the British sea anemones and corals. Van Voorst, London, 362 pp.

Grant, R.E. (1826). Notice of a New Zoophyte (Cliona celata Gr.) from the Firth of Forth. Edinburgh New Philosophical Journal, 1: 78-81.

Gravier, C. (1906). Un Sabellarien vivant sur un Brachiopode (Kingenia alcocki Joubin). Bulletin du Muséum d'Histoire Naturelle, Paris, 12: 540-543.

Hartmeyer, R. (1903). Die Ascidien der Arktis. Fauna Arctica, 3 (2): 91-412.

Hunnam, P. \& Brown, G. (1975). Sublittoral nudibranch Mollusca (sea slugs) in Pembrokeshire waters. Field Studies, 4(2): 131-159.

IHERING, H. VON (1886a). Zur kenntnis der Nudibranchien der brasilianischen kuste. Jahrbücher der Deutschen Malakozoologischen Gesellschaft, 13(3): 223-240.

IHERING, H. VON (1886b). Beiträge zur Kenntnis der Nudibranchien des Mittelmeeres. Part 2. Malakozoologische Blätter N.F., 8: 12-48.

Iredale, T. \& O’Donoghue, C.H. (1923). List of British nudibranchiate Mollusca. Proceedings of the Malacological Society of London, 15(4): 195-200.

Johnson, R.F. \& Gosliner, T.M. (1998). The genus Pectenodoris (Nudibranchia Chromodorididae) from the Indo-Pacific, with the description of a new species. Proceedings of the California Academy of Sciences, series 4, 50(12): 295-306. http://www.biodiversitylibrary.org/page/15659907

Klussmann-Kolb, A.D. (1999). Comparative histology and ultrastructure of the nidamental glands and egg masses of the Opisthobranchia (Mollusca, Gastropoda): a functional and evolutionary approach, vi +188 pp. Ph.D. thesis, University of Bielefeld.

Klussmann-Kolb, A.D. (2001a). Comparative investigation of the genital systems in the Opisthobranchia (Mollusca, Gastropoda) with special emphasis on the nidamental glandular system. Zoomorphology. 120(4): 215235. https://doi.org/10.1007/s004350100041

Klussmann-Kolb, A.D. (2001b). The reproductive systems of the nudibranchia (Gastropoda, Opisthobranchia): Comparative histology 
and ultrastructure of the nidamental glands with aspects of functional morphology. Zoologischer Anzeiger, 240(2): 119-136. https:// doi.org/10.1078/0044-5231-00011

Klussmann-Kolb, A.D. \& Brodie, G.D- (1999). Internal storage and production of symbiotic bacteria in the reproductive system of a tropical marine gastropod. Marine Biology. 133(3): 443-447. https://doi.org/10.1007/ s002270050483

Klussmann-Kolb, A.D. \& Wägele, H. (2001). On the fine structure of opisthobranch egg masses (Mollusca, Gastropoda). Zoologischer Anzeiger, 240(2): 101-118. https://doi. org/10.1078/0044-5231-00010

Kress, A. (1981). A scanning electron microscope study of notum structures in some dorid nudibranchs (Gastropoda: Opisthobranchia). Journal of the Marine Biological Association of the United Kingdom, 61(1): 177-197. https://doi.org/10.1017/S0025315400046002

LAMARCK, J.-B.M. DE(1815). Suite des polypiers empâtés. Mémoires du Muséum d'Histoire naturelle, Paris. 1, 69-80, 162-168, 331-340.

LAmouroux, J.V.F. (1821). Exposition méthodique des genres de l'ordre des polypiers, avec leur description et celle des principales espèces, figurées dans 84 planches; les 63 premières appartenant àl'histoire naturelle des zoophytes d'Ellis et Solander. V. Agasse, Paris, 115 pp.

Lima, P.O.V. \& Simone, L.R.L. (2015). Anatomical review of Doris verrucosa and redescription of Dorisjanuarii (Gastropoda, Nudibranchia) based on comparative morphology. Journal of the Marine Biological Association of the United Kingdom. 95(6): 1203-1220. https://doi.org/10.1017/S0025315415000296

LinNAEus, C. (1758). Systema Naturae per regna tria naturae, secundum classes, ordines, genera, species, cum characteribus, differentiis, synonymis, locis. Editio decima, reformata. Laurentius Salvius: Holmiae. 824 pp.

Linnaeus, C. (1759). Systema naturce per regna trianatura, secundum classes, ordines, genera, species, cum characteribus, differentiis, synonymis, locis. Tomus II. Editio decima, reformata. Laurentius Salvius: Holmiae. 825-1384.

LinNAEus, C. (1767). Systema naturae per regna tria naturae: secundum classes, ordines, genera, species, cum characteribus, differentiis, synonymis, locis. Editio duodecima. 1. Regnum Animale. 1 \& 2 Holmiae, Laurentii Salvii. Stockholm, pp. 1-532 (1766), pp. 533-1327 (1767).

Montagu, G. (1814). An Essay on Sponges, with Descriptions of all the Species that have been discovered on the Coast of Great Britain. Memoirs of the Wernerian Natural History Society, 2 (1): 67-122.

ODHNER, N.H.(1907). Northern and arctic invertebrates in the collection of the swedish state museum (riksmuseum). III. Opisthobranchia and pteropoda. Kungliga Svenska VetenskapsAkademiens Handlingar, 41: 1-113.

Odhner, N.H. (1926). Nudibranchs and lamellariids from the Trondhjem Fjord. Det Kongelige Norske Videnskabernes Selskabs Skrifter, 24: 3-36.

ORTEA, J. (1989). Descripción de algunos moluscos opistobranquios nuevos recolectados en el archipielago de Cabo Verde. Publicações Ocasionais da Sociedade Portuguesa de Malacologia, 13: 17-34.

OrteA, J. (1998). Una nueva especie de Doris Linné, 1758 (Mollusca: Nudibranchia: Doridbdae) de las Islas de Cabo Verde descrita en honor del Dr. Nácere Hayek, Premio Canarias de Investigación. Revista Academia Canaria de las Ciencias, X(4): 115-120.

Ortea, J. \& Bacallado, J. (1981). Les Dorididae (Gastropoda) décrits des Canaries par Alcide d'Orbigny. Bulletin du Muséum National d'Histoire Naturelle, series 4, Section A Zoologie Biologie et Ecologie Animales, 3(3): 767-776.

Ortea, J. \& Espinosa, J. (2017). Descripción de una nueva babosa del azar (Mollusca: Nudibranchia) del Mar Caribe. Avicennia, 21: 55-58.

Ortea, J. \& Moro, L. (2017). Redescripcion de Staurodoris atypica Eliot, 1906 y nuevas citas de "lesmas do mar" (Mollusca: Heterobranchia) para las islas de Cabo Verde. Avicennia, 20: 15-20.

Ortea, J., Moro, L., Bacallado, J.J. \& CabaLLER, M. (2014). Nuevas especies y primeras citas de babosas marinas (Mollusca: Opisthobranchia) en las islas Canarias y en otros 
archipiélagos de la Macaronesia. Vieraea, 42: 47-77.

Ortea, J. \& Urgorri, V. (1978). El género Doto Oken, 1815 en el Norte y Noroeste de España. Boletín de la Estación Central de Ecología, 7(14): 73-92.

Ortea, J. \& Urgorri, V. (1979a). Sobre la presencia de Dendrodoris racemosa Pruvot-Fol, 1951 y Discodoris rosi Ortea, 1977 (Gastropoda: Nudibranchia) en Galicia. Trabajos Compostelanos de Biología, 8: 71-78.

Ortea, J. \& Urgorri, V. (1979b). Primera cita de Hancokia uncinata (Hesse, 1872) (Gastropoda: Nudibranchia) para el litoral ibérico. Trabajos Compostelanos de Biología, 8: 79-86.

Ortea, J. \& Urgorri, V. (1981a). Runcina ferruginea Kress, 1977 et Pruvotfolia pseillotes (Labbé, 1923) dans les eaux iberiques. Vie et Milieu, 31(2): 149-151.

Ortea, J. \& Urgorri, V. (1981b). Opistobranquios nuevos para el litoral ibérico colectados en Galicia. I. Boletín del Instituto Español de Oceanografía, 6: 49-60.

Pallas, P.S. (1766). Elenchus zoophytorum sistens generum adumbrationes generaliores et specierum cognitarum succintas descriptiones, cum selectis auctorum synonymis. Fransiscum Varrentrapp, Hagae, 451 pp.

Pease, W.H. (1860). Descriptions of new species of mollusca from the Sandwich Islands. Proceedings of the Zoological Society of London, 28: 18-36.

Penney, B.K. (2006). Morphology and biological roles of spicule networks in Cadlina luteomarginata (Nudibranchia, Doridina). Invertebrate Biology, 125(3): 222-232. https:// doi.org/10.1111/j.1744-7410.2006.00055.x

Penney, B.K. (2008). Phylogenetic comparison of spicule networks in cryptobranchiate dorid nudibranchs (Gastropoda, Euthyneura, Nudibranchia, Doridina). Acta Zoologica (Copenhagen), 89(4): 311-329. https://doi. org/10.1111/j.1463-6395.2008.00320.x

Penney, B.K., Ehresmann, K.R., Jordan, K.J. \& Rufo, G. (2018). Micro-computed tomography of spicule networks in three genera of dorid sea-slugs (Gastropoda: Nudipleura: Doridina) shows patterns of phylogenetic significance. Acta Zoologica, 101(1): 5-23. https://doi.org/10.1111/azo.12266
Penney, B.K., Sigwart, J.D. \& Parkinson, D.Y. (2020). Spicules and skeletons: mantle musculature of two species of dorid nudibranchs (Gastropoda: Nudibranchia: Doridina). $\mathrm{Ca}$ nadian Journal of Zoology, 98(12): 777-786. https://doi.org/10.1139/cjz-2019-0295

Perrone, A.S. (1989). Una specie de nudibranchi doridiani nuova per il mediterraneo: dati sulla morfologia di Doris bertheloti (d'Orbigny, 1839) (Opisthobranchia, Nudibranchia). Bollettino Malacologico, 24(9-12): 237-242.

Pruvot-Fol, A. (1962). Deux très rares nudibranches de la Méditerranée. Bulletin de la Société Zoologique de France, 87: 566-569.

Pruvot-Fol, A. (1954). Mollusques Opisthobranches. Faune de France. Federation Française des Sociétés de Sciences Naturelles. Office Central de Faunistique. Paul Lechevalier. Paris, 460 pp.

RAFINESQUe, C.S. (1815). Analyse de la Nature ou Tableau de l'univers et des corps organisés. Palerme, 1-224

RAPP, W.L. VON (1827). Ueber das Molluskengeschlecht Doris und Beschreibung einiger neue Arten derselben. Nova Acta Academiae Caesareae Leopoldino-Carolinae Naturae Curiosorum, 13(2): 516-522.

Richthofen, F. von (1886). Führer Für Forschungsreisen. Verlag Robert Oppenheim, Berlin, 745 pp.

Risso, A. (1818). Mémoire sur quelques Gastropodes nouveaux, Nudibranches et Tectibranches observés dans la mer de Nice. Journal de Physique, de Chimie, d'Histoire Naturelle et des Arts, 87: 368-377

Risso, A. (1826). Histoire naturelle des principales productions de l'Europe Méridionale et particulièrement de celles des environs de Nice et des Alpes Maritimes. Vol. IV. Levrault, Paris, 439 pp.

Rolán, E. (1983). Moluscos de la Ría de Vigo. I. Gasterópodos. Thalassas, 1(1) Supl. 1, 383 pp.

Ros, J. (1976). Sistemas de defensa en los Opistobranquios. Oecologia Aquatica, 2: 41-77.

Rudman, W.B. (1985). The Chromodorididae (Opisthobranchia: Mollusca) of the Indo-West Pacific: Chromodoris aureomarginata, $C$. verrieri and $C$. fidelis colour groups. Zoological Journal of the 
Linnean Society, 83(3): 241-299. https://doi. org/10.1111/j.1096-3642.1985.tb00875.x

Rudman, W.B. (1987). The Chromodorididae (Opisthobranchia, Mollusca) of the Indo-West Pacific: Chromodoris epicuria, C. aureopurpurea, C. annulata, C. coi and Risbecia tryoni colour groups. Zoological Journal of the Linnean Society, 90(4): 305-407. https:// doi.org/10.1111/j.1096-3642.1987.tb01357.x

Schmekel, R.L. (1968). Die Gattung Doris (Gastr. Nudibranchia) im Golf von Neapel. Pubblicacioni della Stazione Zoologica di Napoli, 36: 167-187.

Schmekel, R.L. (1971). Histologie und Feinstruktur der Genitalorgane von Nudibranchiern(Gastropoda, Euthyneura). Zeitschrift für Morphologie und Ökologie der Tiere, 69(2): 115-183, 22 pls.

Schmekel, L. \& Portmann, A. (1982). Opisthobranchia des Mittelmeeres. Nudibranchia und Sacoglossa. Fauna e flora del Golfo di Napoli 40: 1-410. Springer-Verlag. Berlin.

Stiasny, G. (1937). Gorgonaria von Setubal. Arquivos do Museu Bocage, 8: 1-18.

Stokes, L. \& Broderip, W.J. (1828). Note. Description of Caryophyllia smithii $\mathrm{n}$. sp. The Zoology Journal, 3: 485-486.

Thompson, T.E. (1960). Defensive adaptations in Opisthobranchs. Journal of the Marine Biological Association of the United Kingdom, 39(1): 123-134. https://doi.org/10.1017/ S0025315400013163

Thompson, T.E. (1961). The importance of the larval Shell in the classification of the Sacoglossa and the Acoela (Gastropoda Opisthobranchia). Proceedings of the Malacological Society of London, 34: 233-238. https://doi. org/10.1093/oxfordjournals.mollus.a064867

Thompson, T.E. \& Brown, G.H. (1984). Biology of opisthobranchmolluscs. Vol.2, Ray Society. London, $229 \mathrm{pp}$.

Trigo, J.E., Díaz-Agras, G.J., García-Álvarez, O.L., Guerra, A., Moreira, J., Pérez, J., RoLÁn, E., Troncoso, J.S. \& URGorri, V. (2018). Guía de los Moluscos Marinos de Galicia. Troncoso, J.S., Trigo, J.E., Rolán, E. (Eds.). Servizo de Publicacións da Universidade de Vigo. 836 pp.

Trigo, J.E. \& Otero-Schmitt, J.J. (1987). Contribución al conocimiento de los Moluscos
Marinos de la Ría de Pontevedra e Isla de Ons. Iberus, 7(1): 121-128.

Urgorri, V. (1981). Opistobranquios de Galicia: estudio faunístico y zoográfico. Tesis Doctoral (Ph.D. Thesis). Universidade de Santiago de Compostela. Santiago de Compostela, $569 \mathrm{pp}$.

Urgorri, V. \& Besteiro, C. (1983). Inventario de los Moluscos Opistobranquios de Galicia. Investigación Pesquera, 47(1): 21-22.

Urgorri, V. \& Besteiro, C. (1984). La alimentación de los Moluscos Nudibranquios de Galicia. Iberus, 4: 51-58. https://www.biodiversitylibrary.org/page/32802827\#page/433/ mode/1up

Urgorri, V. \& Díaz-Agras, G. (2019). Mycale (Aegogropila) antiae sp. nov. (Demospongiae; Poecilosclerida; Mycalidae) from Galicia (NW Iberian Peninsula). Zootaxa, 4550(2): 151-184. https://doi.org/10.11646/zootaxa.4550.2.1

Urgorri, V., Díaz-Agras, G., Besteiro, C. \& Montoto, G. (2011). Additions to the inventory of Mollusca Opisthobranchia of Galicia (NW Iberian Peninsula). Thalassas, 27(2): 77-100. http://thalassas.webs.uvigo. es/Thalassas $\% 2027(2) / A r t \% 2006 \_T h a l a s-$ sas $\% 2027 \% 20(2)$.pdf

VAldÉs, A. (2001). Deep-sea cryptobranch dorid nudibranchs (Mollusca, Opisthobranchia) from the tropical West Pacific, with descriptions of two new genera and eighteen new species. Malacologia, 43: 237311. https://www.biodiversitylibrary.org/ item/47346\#page/245/mode/1up

VALDÉs, A. (2002). A phylogenetic analysis and systematic revision of the crytobranch dorids (Mollusca, Nudibranchia, Anthobranchia). Zoological Journal of The Linnean Society, 136: 535-636. https://doi.org/10.1046/j.10963642.2002.00039.x

VAldÉs, A.\& CAMPILlo, O.A. (2000). Redescription and reassessment of Cadlina luarna (Ev. Marcus and Er. Marcus, 1967), comb. nov. (Mollusca, Opisthobranchia, Doridina). Proceedings of the California Academy of Sciences, series 4, 52(7): 77-85. https://www.biodiversitylibrary.org/page/15778397\#page/93/ mode/1up

WäGEle, H. (1985). The anatomy and histology of Phyllidia pulitzeri Pruvot-Fol, 1962, with 
remarks on the three Mediterranean species of Phyllidia (Nudibranchia, Doridacea). Veliger, 28(1): 63-79. https://www.biodiversitylibrary.org/page/42480179\#page/69/ mode/1up

WÄGELE, H. (1989). Histologische Untersuchungen des Genitaltraktes einiger antarktischer Nudibranchia(Gastropoda, Mollusca). Zoologische Jahrbücher, Abtheilung für Anatomie, 119: 107-128.

Wägele, H., Brodie, G. \& Klussmann-Kolb, A. (1999). Histological investigations on Dendrodorisnigra(Stimpson, 1855)(Gastropoda,
Nudibranchia, Dendrodorididae). Molluscan Research, 20(1): 79-94. https://doi.org/10.10 80/13235818.1999.10673725

Wilson, N.G. (2002). Egg masses of chromodorid nudibranchs (Mollusca: Gastropoda: Opisthobranchia). Malacologia, 44(2): 289305. https://www.biodiversitylibrary.org/ item/47347\#page/297/mode/1up

WoRMS Editorial Board (2021). MolluscaBase. Doris Linnaeus, 1758. Accessed through: World Register of Marine Species at: http://www.marinespecies.org/aphia. php? $p=$ taxdetails\&id $=137914$ on 2021-01-28

Table 1. Genetic distance matrix showing the uncorrected pairwise identity (i.e. proportion of identical sites in the barcode fragment) between sequences of Doris adrianae sp. nov and other Doris species. Sequences have been downloaded from GenBank and one sequence has been selected per species (according to GenBank identity). GenBank accession numbers are also provided.

Tabla 1. Matriz de distancia genética que muestra la identidad por pares no corregida (es decir, la proporción de sitios idénticos en el fragmento del "barcode") entre las secuencias de Doris adrianae sp. nov. y otras especies de Doris. Las secuencias se han descargado de GenBank y se ha seleccionado una secuencia por especie (según la identidad de GenBank). También se proporcionan los números de acceso de GenBank.

\begin{tabular}{|c|c|c|c|c|c|c|c|c|c|c|}
\hline & 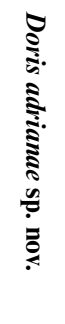 & 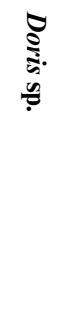 & 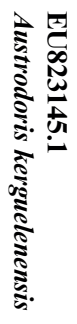 & 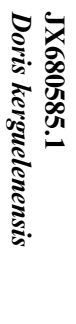 & 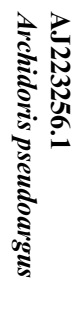 & 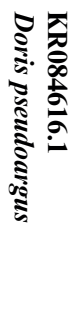 & 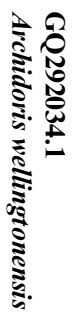 & 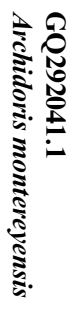 & 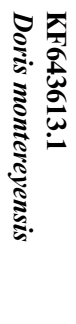 & 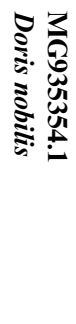 \\
\hline Doris adrianae sp. nov. & 100 & 78.3 & 78.9 & 80.2 & 82 & 82.6 & 80.3 & 81 & 80.9 & 82.8 \\
\hline Doris sp. & 78.3 & 99.8 & 79.3 & 79.9 & 76.7 & 77 & 77.4 & 76.8 & 76.7 & 77.3 \\
\hline $\begin{array}{l}\text { EU823145.1 } \\
\text { Austrodoris kerguelenensis }\end{array}$ & 78.9 & 79.3 & 100 & 95.1 & 81.8 & 81.8 & 79.7 & 80.4 & 80.5 & 82.3 \\
\hline $\begin{array}{l}\text { JX680585.1 } \\
\text { Doris kerguelenensis }\end{array}$ & 80.2 & 79.9 & 95.1 & 100 & 82.3 & 82.1 & 80.2 & 81.3 & 81.3 & 82.6 \\
\hline $\begin{array}{l}\text { AJ223256.1 } \\
\text { Archidoris pseudoargus }\end{array}$ & 82 & 76.7 & 81.8 & 82.3 & 99.2 & 98.5 & 84 & 86.6 & 86.2 & 99 \\
\hline $\begin{array}{l}\text { KR084616.1 } \\
\text { Doris pseudoargus }\end{array}$ & 82.6 & 77 & 81.8 & 82.1 & 98.5 & 100 & 84.1 & 87.3 & 86.8 & 99.4 \\
\hline $\begin{array}{l}\text { GQ292034.1 } \\
\text { Archidoris wellingtonensis }\end{array}$ & 80.3 & 77.4 & 79.7 & 80.2 & 84 & 84.1 & 100 & 84.6 & 83.3 & 84.6 \\
\hline $\begin{array}{l}\text { GQ292041.1 } \\
\text { Archidoris montereyensis }\end{array}$ & 81 & 76.8 & 80.4 & 81.3 & 86.6 & 87.3 & 84.6 & 100 & 99.3 & 87.3 \\
\hline $\begin{array}{l}\text { KF643613.1 } \\
\text { Doris montereyensis }\end{array}$ & 80.9 & 76.7 & 80.5 & 81.3 & 86.2 & 86.8 & 83.3 & 99.3 & 100 & 86.6 \\
\hline $\begin{array}{l}\text { MG935354.1 } \\
\text { Doris nobilis }\end{array}$ & 82.8 & 77.3 & 82.3 & 82.6 & 99 & 99.4 & 84.6 & 87.3 & 86.6 & 100 \\
\hline
\end{tabular}


Appendix 1. Accession number and identification of sequences downloaded from GenBank on December 2020. Apéndice 1. Número de acceso e identificación de las secuencias descargadas de GenBank en diciembre de 2020.

\begin{tabular}{|c|c|c|c|c|c|}
\hline $\begin{array}{c}\text { GenBank } \\
\text { Accession } \\
\text { Number }\end{array}$ & Species & $\begin{array}{c}\text { GenBank } \\
\text { Accession } \\
\text { Number }\end{array}$ & Species & $\begin{array}{c}\text { GenBank } \\
\text { Accession } \\
\text { Number }\end{array}$ & Species \\
\hline AJ223256.1 & Archidoris pseudoargus & EU823185.1 & Austrodoris kerguelenensis & JX680547.1 & Doris kerguelenensis \\
\hline EU823127.1 & Austrodoris kerguelenensis & EU823186.1 & Austrodoris kerguelenensis & JX680548.1 & Doris kerguelenensis \\
\hline EU823128.1 & Austrodoris kerguelenensis & EU823187.1 & Austrodoris kerguelenensis & JX680549.1 & Doris kerguelenensis \\
\hline EU823129.1 & Austrodoris kerguelenensis & EU823188.1 & Austrodoris kerguelenensis & JX680550.1 & Doris kerguelenensis \\
\hline EU823130.1 & Austrodoris kerguelenensis & EU823189.1 & Austrodoris kerguelenensis & JX680551.1 & Doris kerguelenensis \\
\hline EU823131.1 & Austrodoris kerguelenensis & EU823190.1 & Austrodoris kerguelenensis & JX680552.1 & Doris kerguelenensis \\
\hline EU823132.1 & Austrodoris kerguelenensis & EU823191.1 & Austrodoris kerguelenensis & JX680553.1 & Doris kerguelenensis \\
\hline EU823133.1 & Austrodoris kerguelenensis & EU823192.1 & Austrodoris kerguelenensis & JX680554.1 & Doris kerguelenensis \\
\hline EU823134.1 & Austrodoris kerguelenensis & EU823193.1 & Austrodoris kerguelenensis & JX680555.1 & Doris kerguelenensis \\
\hline EU823135.1 & Austrodoris kerguelenensis & EU823194.1 & Austrodoris kerguelenensis & JX680556.1 & Doris kerguelenensis \\
\hline EU823136.1 & Austrodoris kerguelenensis & EU823195.1 & Austrodoris kerguelenensis & JX680557.1 & Doris kerguelenensis \\
\hline EU823137.1 & Austrodoris kerguelenensis & EU823196.1 & Austrodoris kerguelenensis & JX680558.1 & Doris kerguelenensis \\
\hline EU823138.1 & Austrodoris kerguelenensis & EU823197.1 & Austrodoris kerguelenensis & JX680559.1 & Doris kerguelenensis \\
\hline EU823139.1 & Austrodoris kerguelenensis & EU823198.1 & Austrodoris kerguelenensis & JX680560.1 & Doris kerguelenensis \\
\hline EU823140.1 & Austrodoris kerguelenensis & EU823199.1 & Austrodoris kerguelenensis & JX680561.1 & Doris kerguelenensis \\
\hline EU823141.1 & Austrodoris kerguelenensis & EU823200.1 & Austrodoris kerguelenensis & JX680562.1 & Doris kerguelenensis \\
\hline EU823142.1 & Austrodoris kerguelenensis & EU823201.1 & Austrodoris kerguelenensis & JX680563.1 & Doris kerguelenensis \\
\hline EU823143.1 & Austrodoris kerguelenensis & EU823202.1 & Austrodoris kerguelenensis & JX680564.1 & Doris kerguelenensis \\
\hline EU823144.1 & Austrodoris kerguelenensis & EU823203.1 & Austrodoris kerguelenensis & JX680565.1 & Doris kerguelenensis \\
\hline EU823145.1 & Austrodoris kerguelenensis & EU823204.1 & Austrodoris kerguelenensis & JX680566.1 & Doris kerguelenensis \\
\hline EU823146.1 & Austrodoris kerguelenensis & EU823205.1 & Austrodoris kerguelenensis & JX680567.1 & Doris kerguelenensis \\
\hline EU823147.1 & Austrodoris kerguelenensis & EU823206.1 & Austrodoris kerguelenensis & JX680568.1 & Doris kerguelenensis \\
\hline EU823148.1 & Austrodoris kerguelenensis & EU823207.1 & Austrodoris kerguelenensis & JX680569.1 & Doris kerguelenensis \\
\hline EU823149.1 & Austrodoris kerguelenensis & EU823208.1 & Austrodoris kerguelenensis & JX680570.1 & Doris kerguelenensis \\
\hline EU823150.1 & Austrodoris kerguelenensis & EU823209.1 & Austrodoris kerguelenensis & JX680571.1 & Doris kerguelenensis \\
\hline EU823151.1 & Austrodoris kerguelenensis & EU823210.1 & Austrodoris kerguelenensis & JX680572.1 & Doris kerguelenensis \\
\hline EU823152.1 & Austrodoris kerguelenensis & EU823211.1 & Austrodoris kerguelenensis & JX680573.1 & Doris kerguelenensis \\
\hline EU823153.1 & Austrodoris kerguelenensis & EU823212.1 & Austrodoris kerguelenensis & JX680574.1 & Doris kerguelenensis \\
\hline EU823154.1 & Austrodoris kerguelenensis & EU823213.1 & Austrodoris kerguelenensis & JX680575.1 & Doris kerguelenensis \\
\hline EU823155.1 & Austrodoris kerguelenensis & EU823214.1 & Austrodoris kerguelenensis & JX680576.1 & Doris kerguelenensis \\
\hline EU823156.1 & Austrodoris kerguelenensis & EU823215.1 & Austrodoris kerguelenensis & JX680577.1 & Doris kerguelenensis \\
\hline EU823157.1 & Austrodoris kerguelenensis & EU823216.1 & Austrodoris kerguelenensis & JX680578.1 & Doris kerguelenensis \\
\hline EU823158.1 & Austrodoris kerguelenensis & EU823217.1 & Austrodoris kerguelenensis & JX680579.1 & Doris kerguelenensis \\
\hline EU823159.1 & Austrodoris kerguelenensis & EU823218.1 & Austrodoris kerguelenensis & JX680580.1 & Doris kerguelenensis \\
\hline EU823160.1 & Austrodoris kerguelenensis & GQ292034.1 & Archidoris wellingtonensis & JX680581.1 & Doris kerguelenensis \\
\hline EU823161.1 & Austrodoris kerguelenensis & GQ292035.1 & Doris kerguelenensis & JX680582.1 & Doris kerguelenensis \\
\hline EU823162.1 & Austrodoris kerguelenensis & GQ292036.1 & Doris kerguelenensis & JX680583.1 & Doris kerguelenensis \\
\hline EU823163.1 & Austrodoris kerguelenensis & GQ292037.1 & Doris kerguelenensis & JX680584.1 & Doris kerguelenensis \\
\hline EU823164.1 & Austrodoris kerguelenensis & GQ292038.1 & Doris kerguelenensis & JX680585.1 & Doris kerguelenensis \\
\hline EU823165.1 & Austrodoris kerguelenensis & GQ292039.1 & Doris kerguelenensis & JX680586.1 & Doris kerguelenensis \\
\hline EU823166.1 & Austrodoris kerguelenensis & GQ292041.1 & Archidoris montereyensis & JX680587.1 & Doris kerguelenensis \\
\hline
\end{tabular}


Apéndice 1. Continuación

\begin{tabular}{|c|c|c|c|c|c|}
\hline EU823167.1 & Austrodoris kerguelenensis & GQ292046.1 & Doris sp. & JX680588.1 & Doris kerguelenensis \\
\hline EU823168.1 & Austrodoris kerguelenensis & GU227115.1 & Austrodoris kerguelenensis & JX680589.1 & Doris kerguelenensis \\
\hline EU823169.1 & Austrodoris kerguelenensis & JX680531.1 & Doris kerguelenensis & KC153022.1 & Doris montereyensis \\
\hline EU823170.1 & Austrodoris kerguelenensis & JX680532.1 & Doris kerguelenensis & KF643435.1 & Doris montereyensis \\
\hline EU823171.1 & Austrodoris kerguelenensis & JX680533.1 & Doris kerguelenensis & KF643446.1 & Doris montereyensis \\
\hline EU823172.1 & Austrodoris kerguelenensis & JX680534.1 & Doris kerguelenensis & KF643613.1 & Doris montereyensis \\
\hline EU823173.1 & Austrodoris kerguelenensis & JX680535.1 & Doris kerguelenensis & KF643914.1 & Doris montereyensis \\
\hline EU823174.1 & Austrodoris kerguelenensis & JX680536.1 & Doris kerguelenensis & KF644212.1 & Doris montereyensis \\
\hline EU823175.1 & Austrodoris kerguelenensis & JX680537.1 & Doris kerguelenensis & KR084378.1 & Doris pseudoargus \\
\hline EU823176.1 & Austrodoris kerguelenensis & JX680538.1 & Doris kerguelenensis & KR084586.1 & Doris pseudoargus \\
\hline EU823177.1 & Austrodoris kerguelenensis & JX680539.1 & Doris kerguelenensis & KR084616.1 & Doris pseudoargus \\
\hline EU823178.1 & Austrodoris kerguelenensis & JX680540.1 & Doris kerguelenensis & KR084907.1 & Doris pseudoargus \\
\hline EU823179.1 & Austrodoris kerguelenensis & JX680541.1 & Doris kerguelenensis & MF958425.1 & Doris montereyensis \\
\hline EU823180.1 & Austrodoris kerguelenensis & JX680542.1 & Doris kerguelenensis & MG422353.1 & Doris montereyensis \\
\hline EU823181.1 & Austrodoris kerguelenensis & JX680543.1 & Doris kerguelenensis & MG935320.1 & Doris pseudoargus \\
\hline EU823182.1 & Austrodoris kerguelenensis & JX680544.1 & Doris kerguelenensis & MG935354.1 & Doris nobilis \\
\hline EU823183.1 & Austrodoris kerguelenensis & JX680545.1 & Doris kerguelenensis & MG935407.1 & Doris pseudoargus \\
\hline EU823184.1 & Austrodoris kerguelenensis & JX680546.1 & Doris kerguelenensis & MH242734.1 & Doris montereyensis \\
\hline
\end{tabular}

